\title{
(8) IEB
}

Instıtut

d'Economia

de Barcelona

\section{IEB Working Paper 2018/16}

LONG-LASTING SOCIAL CAPITAL AND ITS IMPACT ON ECONOMIC

DEVELOPMENT: THE LEGACY OF THE COMMONS

Daniel Montolio, Ana Tur-Prats

Fiscal Federalism

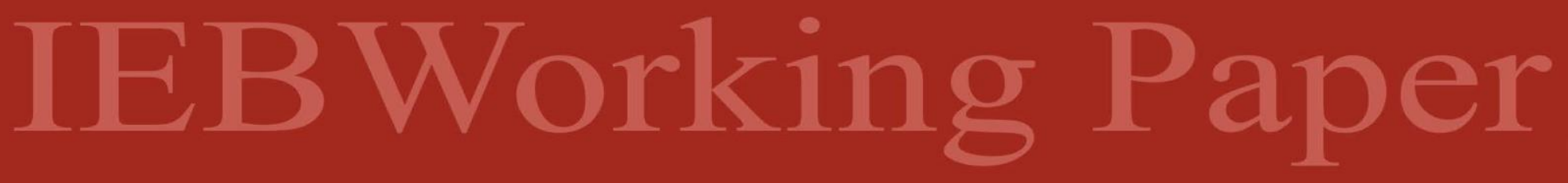




\section{LONG-LASTING SOCIAL CAPITAL AND ITS IMPACT ON ECONOMIC DEVELOPMENT: THE LEGACY OF THE COMMONS}

Daniel Montolio, Ana Tur-Prats

The Barcelona Institute of Economics (IEB) is a research centre at the University of Barcelona (UB) which specializes in the field of applied economics. The IEB is a foundation funded by the following institutions: Applus, Abertis, Ajuntament de Barcelona, Diputació de Barcelona, Gas Natural, La Caixa and Universitat de Barcelona.

The IEB research program in Fiscal Federalism aims at promoting research in the public finance issues that arise in decentralized countries. Special emphasis is put on applied research and on work that tries to shed light on policy-design issues. Research that is particularly policy-relevant from a Spanish perspective is given special consideration. Disseminating research findings to a broader audience is also an aim of the program. The program enjoys the support from the IEB-Foundation and the IEB-UB Chair in Fiscal Federalism funded by Fundación ICO, Instituto de Estudios Fiscales and Institut d'Estudis Autonòmics.

Postal Address:

Institut d'Economia de Barcelona

Facultat d'Economia i Empresa

Universitat de Barcelona

C/ John M. Keynes, 1-11

(08034) Barcelona, Spain

Tel.: + 34934034646

ieb@ub.edu

http://www.ieb.ub.edu

The IEB working papers represent ongoing research that is circulated to encourage discussion and has not undergone a peer review process. Any opinions expressed here are those of the author(s) and not those of IEB. 


\title{
LONG-LASTING SOCIAL CAPITAL AND ITS IMPACT ON ECONOMIC DEVELOPMENT: THE LEGACY OF THE COMMONS *
}

\author{
Daniel Montolio, Ana Tur-Prats
}

\begin{abstract}
This paper analyzes the historical determinants and long-term persistence of social capital, as well as its effect on economic development, by looking at the legacy of the commons in a Spanish region. In medieval times, common goods were granted to townships and were managed collectively by local citizens. This enabled the establishment of institutions for collective action and self-government. Common goods persisted until the second half of the nineteenth century. We argue that the experience of cooperation among villagers, repeated over the centuries, increased the social capital in each local community. In 1845, a law forced small villages to merge with others, a fact which generated exogenous variation in the number of mergers (i.e., cooperative networks) that each modern municipality was required to have. We exploit this change in an IV and RD setting and find that current municipalities formed by a greater number of old townships have a denser network of associations. We also find that higher social capital is associated with more economic development.
\end{abstract}

JEL Codes: N90, P48, Z10, H49

Keywords: Collective action, self-government, long-term persistence, common goods

Daniel Montolio

Universitat de Barcelona \&

Institut d'Economia de Barcelona (IEB)

E-mail: $\underline{\text { montolio@ub.edu }}$
Ana Tur-Prats

University of California, Merced

E-mail: atur-prats@ucmerced.edu

\footnotetext{
${ }^{*}$ We thank Francesc Amat, Sergio Beraldo, Davide Cantoni, Christian Fons-Rosen, Petros Milionis, Maria Petrova, Felipe Valencia and participants at seminars and workshops at Pompeu Fabra University, IPErGUniversitat de Barcelona, ASREC Luxembourg, and EEA Conference 2018 for comments and discussions. Miguel Alquézar and Xavier-Andoni Tibau provided excellent research assistance. The authors acknowledge support from grant ECO2016-75912-R from the Spanish Ministerio de Economía y Competitividad and from grant 2015ACUP 00037 from RECERCAIXA (Obra Social La Caixa). Ana Tur-Prats also acknowledges support from the Marie Curie FP7-PEOPLE-2012-COFUND Action; grant agreement no: 600387. All errors remain our own.
} 


\section{Introduction}

Social capital is a key concept in social sciences. It is considered to be the missing link that can explain why differences in economic performance persist over the centuries (Guiso et al. 2011), and a fundamental ingredient for democracy maintenance and institutional performance (Putnam 1993). In this paper, we aim to understand the historical origins of social capital, document its persistence over time and its effects on economic development. We do this by focusing on the legacy of the commons.

Common goods are resources (forests, pasture, irrigation systems, etc.) that are used and managed collectively according to certain rules. The Spanish region of Catalonia provides an excellent setting for analyzing the commons, for three different reasons. First, their historical origins can be traced back to the resettlement patterns during the Christian conquest of the Iberian Peninsula (eighth to eleventh centuries), by which each newly founded township was granted a set of common lands. These common goods represented a collective-action problem and its solution required a considerable amount of cooperation and mutual trust (Beltrán-Tapia 2012, Ostrom 1990). Our hypothesis is that this experience of cooperation, repeated over centuries, increased the stock of social capital in each township.

Second, common goods persisted for a long time in Catalonia, broadly until the second half of the nineteenth century. At that point in time they disappeared in many townships, especially as a result of the Disentailment Act passed in 1855. This implies that if we find persistence in current measures of social capital, even after the commons have long disappeared, it must be either due to cultural transmission or to an institutional channel different from the one that originated social capital in the first place. Third, for the purpose of identification, we use exogenous variation that a law passed in 1845 generated in the amount of common goods (i.e., cooperative networks) that formed each modern municipality. This law forced small townships ( $\leq 30$ householders, approximately 150 inhabitants) to merge with others. Our research strategy exploits the jump in the probability of merging with another townshipbased only on their population in 1845-in a Regression Discontinuity (RD) setting, as well as in an Instrumental-Variable (IV) approach.

Our measure of current social capital is the number of voluntary associations per capita 
at the municipal level. To analyze the persistence of social capital, we regress our current measure of social capital on our measure of social capital in the past, controlling for a number of demographic, geographic, and climatic characteristics at the municipal level, as well as for unobserved time-invariant differences at the regional level (including district fixed effects). Results show that municipalities formed by a greater number of small townships in the past currently have a denser network of voluntary associations.

An analysis by sub-periods shows that the persistence of social capital is mainly driven by associations which proliferated once the democratic regime was consolidated in Spain. Interestingly, we observe that during Franco's dictatorship period (1939-1975), the relationship between commons and associations is negative. Associations during the autocratic period were restricted in number and their goals had to be in line with the regime's principles, so we cannot consider them as a good proxy of social capital.

To address the potential endogeneity of our measure of social capital in the past (e.g., townships with more cohesive individuals might have voluntarily merged together and have more social capital today) we apply two empirical strategies. First, we implement an IV estimation in which we use as an instrument for social capital in the past the number of townships in the current municipality that merged because of the 1845 Act (i.e., because they had 30 householders or fewer). Second, we apply an RD design in which we compare the outcomes of modern municipalities where the main village's population fell just below or just above the population threshold established by the 1845 Act (again, having more than 30 householders). Results from both identification strategies point in the same direction: municipalities with a greater number of commons in the past currently have more voluntary associations per capita.

We analyze different types of associations based on their main activities (e.g., cultural, civic rights, scientific knowledge, health and social welfare, etc.) and find that the persistence of social capital is mainly driven by the ones that promote civic rights in a particular placetypically, neighborhood associations. Many of these emerged within the boundaries of the old townships rather than in the main town of the modern municipality (see Figure 2). We interpret this as being consistent with our argument that local differences in social capital today stem from the legacy of the commons and the collective-action institutions that arose around them. 
We also investigate the impact of social capital on today's economic development. Our measure of economic development is the average income tax base at the municipal level. Using as an instrument of current social capital the presence of commons in the past, we find that an increase in the modern-day density of associations is related to higher economic development. This impact persists even after controlling for other drivers of economic development, such as human capital, innovation, roads and public infrastructure, financial capital, and police forces.

Then we turn our attention to alternative modern measures of social capital-perceptions of good citizenship, social interaction, and resident engagement-and results point again to a positive relationship between the experiences of cooperation around the commons in the past and today's pro-social behavior. Finally, we look at a transparency index as a measure of quality of governance at the municipal level and we do not find any significant relationship with social capital in the past. Since we do not find any institutional differences, this last finding means to suggest that the cultural channel is the most likely transmission mechanism that explains the long-term persistence of social capital in our setting.

The literature on social capital is long-standing and extensive. Even though we share the same research questions as other studies-namely, where is social capital coming from, whether it persists over time, and its potential effects on economic development-we believe that our paper makes a significant contribution to this literature. First, while most studies have focused on one or two of these questions, we provide a more comprehensive analysis by bringing together the analysis of the origins, long-term persistence as well as the effects of social capital on development in a single study. Second and related to this, we are able to estimate the effects of social capital more accurately by providing a separate theory of its determinants based on the legacy of the commons (which, as Durlauf (2002) points, mitigates concerns about the validity of our instruments), and by relying on a natural experiment that provides a clean identification.

This paper is structured as follows. Section 2 reviews the related literature. Section 3 provides the historical background of the commons in Catalonia, the reforms that modified them, and the municipal map of Catalonia. We establish the conceptual framework in Section 4. Section 5 details the data and explains our empirical strategy. The different set of results are 
discussed in Section 6. Section 7 presents additional results, looking at alternative measures of social capital and at the relationship between social capital in the past and quality of local governance. Finally, Section 8 concludes.

\section{Literature Review}

This paper contributes to previous work on the origins and long-term persistence of social capital. Guiso et al. (2016) study the case of Italian communes (self-governed cities in the Middle Ages) and find that these cities have higher levels of social capital today. Their hypothesis is that these experiences of independence fostered self-efficacy beliefs-beliefs in one's own ability to complete tasks and reach goals-and that this cultural trait was transmitted across generations and explains current social capital.

Buggle and Durante (2017) analyze the effect of environmental factors on cooperation and trust. They find higher levels of trust in those European regions with higher climate variability. Their hypothesis is that pre-industrial farmers needed to cooperate in order to cope with climate risk and that these experiences of cooperation fostered norms of generalized trust that were transmitted over time even after climate was no longer so directly relevant to their economic activity.

This paper focuses instead on an institution for collective action, the commons, that originated far back in history, managed to survive for a long time in rural and small towns, and was widespread around the world, especially in pre-industrial Europe. We are not the first to look at the commons; Beltrán-Tapia has extensively studied the role of the commons in the emergence of agricultural cooperatives (Beltrán-Tapia 2012), in improving human capital (Beltrán-Tapia 2013) and life expectancy and body height (Beltrán-Tapia 2015a), in fostering agricultural productivity (Beltrán-Tapia 2015b) and economic development (Beltrán-Tapia 2016) in Spain, and the geographical persistence of the commons itself (Beltrán-Tapia 2015c). Apart from the fact that we analyze a different outcome variable, namely current social capital, our work differs in two key methodological dimensions. First, while Beltrán-Tapia's work uses measures of common lands at the province level, we propose a novel measure of the commons at the municipal 
level, assuming that each township in the old regime managed a set of common goods. Second, we exploit a historical event-a law enacted in 1845 that modified the municipal map of Catalonia-as a natural experiment to draw causal inference.

Second, this paper contributes to the literature that has examined the effects of social capital on economic development. Knack and Keefer (1997) show that both trust and civic norms have a positive association with economic performance, although they find that associational activity is unrelated to economic performance. Tabellini (2010) finds that European regions with higher endowments of civic capital have higher GDP per capita today and higher growth rates, and instruments current endowment of social capital with historical variables such as literacy rates at the end of the nineteenth century and indicators of political institutions in the 1600-1850 period. In line with this latter paper, we also use a distant historical episode as an instrument for social capital accumulation. On the other hand, we incorporate a separate theory of the determinants of social capital, which mitigates concerns about the validity of our instruments (Durlauf 2002).

The importance of social capital for the functioning of democratic institutions has also been documented. Padró i Miquel et al. (2015) take the presence of temples in Chinese villages as a proxy of social capital and show that after the introduction of elections, those villages with higher social capital experienced larger increases in public goods provision. Even though social capital is typically associated with positive outcomes, there are papers that show a negative influence in specific cases. This is the case of Satyanath et al. (2017), who document that a dense network of voluntary associations facilitated the rise of the Nazi Party by bringing more people into contact with the party message and helping to destroy the democratic system. More generally, our results also add to the growing literature on the persistence of cultural values over long periods of time (Nunn 2012).

Finally, this paper also contributes to the literature on municipal mergers or amalgamations. The bulk of this literature has examined the extent to which municipal amalgamations can harvest economies of scale in the provision of public services, and found mixed or null results (Reingewertz 2012; Blesse and Baskaran 2016; Blom-Hansen, Houlberg, Serritzlew et al. 2016). We extend the focus by looking at the impact of municipal mergers on the accumulation of 
social capital and, in turn, on the economic development of the municipal entity.

\section{Historical Background}

\subsection{The Commons in Catalonia}

The historical origins of the commons in Catalonia can be traced back to the resettlement patterns at the beginning of the Christian conquest (or "Reconquista") of the Iberian Peninsula (eighth to eleventh centuries). During the early stages of the Reconquista, in order to guarantee that the population would remain and defend the conquered territory, Christian kings and nobles granted freedom and extensive privileges to townships under their control. These privileges included the granting of a plot of land to each family for its subsistence as well as the right to self-government to manage common lands that were bestowed upon the township as a whole (Brenan 1990).

Typically, the land surrounding the dwellings would be individually owned by the villagers and devoted to intensive agriculture, and the land around this central core would qualify as common land. Therefore, the borders of the common lands generally coincided with the borders of the townships founded during this period (Viñas et al. 2016). In territories where the township was located near the sea and where land was not the main production factor, the commons originated around other resources, such as fishing grounds and salt flats $1_{1}^{1}$ Catalonia's medieval-law code (Usatges) already established the common use of these goods.2

\footnotetext{
${ }^{1}$ Brenan (1990) compiles different descriptions of these commons in several Spanish villages, many of them located in Catalonia.

${ }^{2}$ The original legal text, largely coded in the eleventh and twelfth centuries, established that "Stradas e vias publicas e ayguas corrents, e fons vivas, prats e pasturas, selvas, garrigas e rocas qui son fundadas en aquest terra son de las potestats, no que ho hajen per alou ne ho tengan en domini, mas que tots temps sien a empriu de lurs pobles, sens tot contrast e sens servici sabut." Kagay (1994) translated it into English as follows: "Highways and public roads, flowing water and fresh water springs, meadows and pastures, forests, coppices, and crags existing in this land are the rulers', not so they may have them as a freehold or hold them in lordship but so for all the time these shall be for the use of all their people without any hindrance or encroachment and the establishment of any tribute."
} 
There were two different types of access to common goods. The first was simultaneous and collective use by all town citizens. The second was the division of the land into lots allocated to individual families of the community for a specified period of time, normally in exchange for a monetary rent. The managing of these common goods represented a collective-action problem; consequently, self-governing institutions such as local assemblies emerged to establish a fair and rational system of use. In Catalonia, these local medieval institutions, known as consells, initially included all the town residents. In the late Middle Ages the decisions were delegated to a restricted group elected by the local assembly, except for small towns which continued to be ruled by the full assembly of residents (Font i Rius 1985).

Common goods and self-governing institutions associated with them generally persisted in Catalonia from early medieval times until the second half of the nineteenth century. Among the factors that contributed to their disappearance we find the full industrialization of the region, the centralization of policies and the greater degree of intervention by the central government. Still, the fundamental drivers of the dismantling of the commons by modernizing governments were the General Disentailment Act (Ley General de Desamortización) promoted by Finance Minister Pascual Madoz in 1855 and the Uplands Act (Ley de Montes) of 1863 (Busqueta and Vicedo 1996). These laws allowed the central government to expropriate the common lands and sell them at public auctions.

There was, however, an exemption to this general rule: municipalities were allowed to keep their common lands if they could prove that they were being actively used by the local villagers. If we accept that common lands were more actively used in townships in which the network was more robust and vibrant (i.e., where social capital was higher), then we could use data on these exemptions from disentailment to support our hypothesis-namely, that social capital was higher in municipalities formed by a larger number of townships. We have collected data from a public inventory of the exemptions published in 1901 3 These results are shown in Table 11 in the appendix. We find a positive correlation between the number of old townships that formed a modern municipality and the existence of common lands exempted

\footnotetext{
${ }^{3}$ This catalog completed and updated the previous one published in 1862, and was the result of the Royal Decree of February $27^{\text {th }}, 1897$. The original title in Spanish is "Catálogo de los Montes Públicos y demás terrenos forestales exceptuados de la desamortización por razones de utilidad pública".
} 
from public auction. The results are consistent to alternative definitions of the dependent variable. Column (1) and (2) show the marginal effects from a probit model in which the dependent variable is a binary variable that takes the value 1 if there was any exemption in the municipality (12\% of the modern municipalities obtained an exemption). Columns (3) and (4) show the results of a Poisson model in which the dependent variable is defined as the share of municipal land which was exempted from disentailment.

\subsection{The 1845 Act and the Mergers of Townships}

In 1845, in the midst of a liberal reform, a law forced small townships to merge with others $4^{4}$ This Town Councils Act (1845) established in article 70 that "town councils with populations of more than 30 householders shall be preserved [...]. Town councils with a smaller population shall merge with another or else gather together and form a new town council" [5 A householder (vecino in the law) is defined as the head of a household, and demographers and historians assume that 1 householder equals 5 inhabitants.

Figure 1 shows changes in the municipal map of Catalonia in the period 1800-2015. The current 948 Catalan municipalities are the result of more than 200 years of mergers and divisions. Our calculations, based on work done by geographers (Burgueño and Lasso de la Vega 2002), show that in year 1800 there were 2,131 municipal entities (townships) in Catalonia. In the last 200 years 1,192 townships (56\% of the total) were merged; 488 current municipalities are the same as in 1800 (23\%); and 392 townships have become the core village or town of a modern (merged) municipality (18\%). The remaining 59 current municipalities $(3 \%)$ were newly established as a result of some division process occurred during this period.

From the total 1,192 mergers, 691 (58\%) occurred during the period 1845-1854 as a result of the 1845 Act. We have digitally compiled the maps that show changes in municipal boundaries

\footnotetext{
${ }^{4}$ Law about the Organization and Conferring of Town Councils (Ley de Organización y Atribuciones de los Ayuntamientos), sanctioned by Queen Isabella II on January $8^{\text {th }}, 1845$.

${ }^{5}$ Translation by the authors. Original text: "Se conservarán todos los ayuntamientos que hoy existen en poblaciones de más de 30 vecinos, arreglando su organización á las disposiciones de esta ley. Los de menor vecindario se agregarán á otros, o formarán, reuniéndose entre sí, nuevos ayuntamientos."
} 
and added some geographic information. By doing this, we find that $85.3 \%$ of the mergers can be explained by exogenous characteristics of the townships involved 6

In general, the merging process did not erase small local communities; rather, they integrated as a distinct community within the new municipality and have remained as such. To show this, we have computed the percentage of built-up land that corresponds to the merged townships. By combining cartographic information for 2009 on different types of land cover (forests, crops, urban areas, etc.) with our map of historical townships, we have found that, on average, $36.8 \%$ of the built-up land in the modern municipality corresponds to the old merged townships.

We also compute a municipality fractionalization index, that is, the probability that two individuals living in the same municipality live in different settlement areas (villages or modern developments). Using data from the 2011 census, we find that those municipalities that experienced mergers in the past have a higher fractionalization index $(45.6 \%)$ than those municipalities that did not (28.7\%). In addition, the percentage of people living in settlement areas with less than 300 inhabitants is much higher in municipalities formed by merged townships $(46.5 \%)$ than in those municipalities that remained intact (35.1\%). Furthermore, we find that $21 \%$ of the voluntary associations in our dataset are located in the old townships, rather than in the main town or village of the modern municipality.

\section{Conceptual Framework}

Common goods are resources that are used collectively. We follow a broad definition of common goods that includes land (woodland, grassland or arable land), as well as other types of resources, such as irrigation systems, fisheries or mills. The management of the commons cor-

\footnotetext{
${ }^{6}$ More precisely, $56.6 \%$ of the mergers took place between the old township and the closest current capital of the municipality; $14.2 \%$ occurred between townships that were close to each other and one of them had as the nearest neighbor the capital of the current municipality; finally, 3.6\% of mergers were with the closest township within the same judiciary district. The remaining $10.9 \%$ of mergers which did not comply with the shortest distance criteria could instead be explained by being in the area of influence of an important municipality ( $5.1 \%$ of mergers) or for geographical reasons (5.8\%).
} 
responds to the local community. Institutions for collective action arose in order to profit from the advantages that cooperation could offer (such as economies of scale and risk sharing) and given the long-lasting nature of these communal arrangements (De Moor 2008). These institutions regulated the use of the resources to avoid depletion and were mostly self-governed and self-enforced, in the sense that their members were responsible for punishing deviant behaviors and solving any potential conflict.

As Ostrom (1990) shows, the successful solution to these coordination problems requires a considerable amount of mutual trust and cooperation among individuals. Our hypothesis, supported by Beltrán-Tapia (2012) and Font i Rius (1985), is that this practice, repeated over centuries, increased the stock of social capital in each local community. When these small local communities or townships merged together, the resulting municipalities accumulated a number of different cooperative experiences and social networks. Compared to a municipality in which nothing happened, a newly formed municipality contained multiple robust yet distinct and non-overlapping social networks. The key empirical question is thus whether social capital at the municipal level would be strengthened or undermined by the presence of segregated cooperative networks in merged municipalities. On a theoretical level, Boix and Posner (1996) argue that the former will be most likely true for high levels of social capital. Under this scenario, individuals from strong and consolidated networks would be more keen to establish connections with different networks; if their attempts fail, they will easily find backup in their original network.

Shortly after small townships were forced to merge-around mid-nineteenth century-, commons and collective-action institutions ceased to exist in most of the municipalities. We therefore hypothesize that if we find any persistence in social capital, even after the commons have long disappeared, it is due to its inter-generational transmission. As Guiso et al. (2011) argue, social capital is highly persistent since its transmission channels-intra-family transmission, formal education and socialization - take a long time.

Following Putnam et al. (1993) and Guiso et al. (2016), among others, our measure of contemporary social capital is the number of voluntary associations per capita. We provide more information on how we construct our measures of social capital in the next section. As soon as 
freedom of association was enshrined in the 1978 Constitution, voluntary associations-some of which constituted formalizations of pre-existing networks-started to emerge throughout the country. Interestingly, as shown in Figure 2, the civic rights associations (typically neighborhood associations) that were registered in Catalonia during the period 1997 to 2015-after a Catalan law fully materialized the constitutional right-are located within the boundaries of the townships, rather than in the main town or village of the municipality. This provides additional evidence for our hypothesis that social capital was originated around the commons.

\section{Data and Empirical Strategy}

\subsection{Data and Descriptive Statistics}

Our measure of social capital in the past is based on the presence of commons in each old township. Padró i Miquel et al. (2015) use a similar proxy for social capital in China, namely the presence of village temples. They argue that these village-wide voluntary associations require collective action to be constructed and maintained. The underlying assumptions that we make, based on historical evidence, are that townships in the premodern era were mainly founded during the early stages of the Christian conquest and that each township was endowed with a set of common goods.

In order to obtain variation in the number of commons in the past, we exploit the fact that small townships merged to form modern municipalities. As we have explained above, in the region we study - Catalonia-there were more than 2,000 townships pre-1845 while currently there are only 948 . We therefore measure social capital in the past as the number of townships (i.e., the number of networks which emerged around common goods) that a current municipality had in 1800.

Following Putnam (1993), Buonanno et al. (2009) and Guiso et al. (2016), among others, we use the number of voluntary associations per capita at the municipal level as our measure of contemporary social capital. Data on associations comes from the Department of Justice of the Government of Catalonia and contains all legal entities registered in Catalonia from 1942 
to 2015.7

In total, 70,593 entities were registered during this period in Catalonia, most of them only after Spain transitioned into a democratic regime (1978). In 1941, two years after General Franco had won the Civil War (1936-1939) and established a dictatorship, a decree banning associations was passed. More than two decades later, Act 191/1964 approved the establishment of certain types of associations - those that were in line with the principles of the regime-subject to the authorization of governmental authorities. Freedom of association was recognized as a fundamental right in article 22 of the 1978 Constitution, adopted three years after General Franco's death, but the prior authorization requirement remained in force. We therefore cannot assume that the organizations registered under the dictatorship are a good proxy for social capital, and accordingly, we will conduct our analysis by sub-periods. In 1997, the Parliament of Catalonia passed a law fully implementing the constitutional right of association 8 it replaced the 1964 Act and removed the requirement.

The Catalan Associations Act (Llei d'Associacions) provides for the creation of a register of "entities" (Registre d'Entitats). Associations are, by far, the most common type of legal entity registered (95\%), and are defined as non-profit organizations, voluntarily formed by three or more individuals to serve a general or specific interest, through the sharing of personal resources, temporarily or indefinitely. The second most common type of organization registered are foundations (3.6\%). The most significant difference between an association and a foundation is that the creation of a foundation requires assets and it can only pursue general-interest objectives. Moreover, the governing bodies of an association are the general assembly and the board of directors, while the foundation has a board of trustees. The remaining types of legal entities in the register are federations $(1.14 \%)$, professional associations $(0.21 \%)$ and religious entities $(0.10 \%)$ ?

According to their main purpose, these organizations can be classified as serving to promote culture $(45 \%)$, civic rights $(12 \%)$, scientific knowledge and learning $(10.3 \%)$, economic

\footnotetext{
${ }^{7}$ Table 12 in the appendix lists all data sources.

${ }^{8}$ Law 7/1991, of June $18^{\text {th }}$, on Associations.

${ }^{9}$ We refer in this text to "associations" as they constitute the bulk of entities and best reflect the type of social capital we are focusing on, but in fact have included all types of entities in the register in our data.
} 
interests of certain groups (i.e., lobbying) $(10 \%)$, social care and health $(7.3 \%)$ and environmental protection $(4.8 \%)$. 10

\subsection{Empirical Strategy}

To analyze the persistence of social capital, we first regress our contemporary measure of social capital (associations at the municipal level per 1,000 inhabitants) on our measure of social capital in the past (number of old townships that formed the municipality), controlling for a number of characteristics at the municipal level, as well as for unobserved time-invariant differences at the local (district) level 11

$$
y_{i}=\alpha+\beta x_{i}+\gamma \text { covariates }_{i}+\lambda_{r} \text { district }_{r}+\epsilon_{i}
$$

where $y_{i}$ is the number of associations per 1,000 inhabitants in municipality $i, x_{i}$ is the number of old townships that form the current municipality, covariates $s_{i}$ is a vector of covariates, and $\epsilon_{i}$ is the error term. Our hypothesis is that municipalities with more communal goods in the past currently have a denser network of associations.

The main concern with equation (1) is that $x_{i}$ might not be exogenous. For instance, townships with more social-minded individuals might have voluntarily merged together and have more social capital today. To address this concern we take advantage of a natural experiment: we exploit the variation that the 1845 Act generated in the number of townships that each modern municipality has, based only on their population in 1845. Our first approach uses the number of townships that merged with others because they had $\leq 30$ householders in 1845 as an instrument for the total number of townships that form the current municipality.

Because our instrument is correlated with having small townships with a lower population count, a potential threat to the validity of this instrument arises. The exclusion restriction would be violated if, for instance, the population dynamics that determined having lower pop-

\footnotetext{
${ }^{10}$ The remaining share $(10.7 \%)$ appears as 'unclassified' in the dataset.

${ }^{11}$ The judicial districts (partidos judiciales, also termed "districts" in this text) are the territorial units for the administration of justice. The first division into these administrative units dates from 1834 . There are 49 judicial districts in Catalonia.
} 
ulation had a direct influence on contemporary social capital. This would be the case if, for instance, some unobserved characteristic of the terrain had kept the population from growing and at the same time exerted a negative impact on social capital today. As we explain in detail below, to account for this we apply two different strategies. First, we restrict our IV estimation to a sub-sample of small municipalities which have, by definition, similar population dynamics. Second, we rely on an RD strategy in which we exploit the fact that there is a discontinuous change in the number of total townships subsumed into the modern main town or village as a function of its having a population of more than 30 householders, and we compare the associational density of municipalities that fell just below or just above the population threshold established by the 1845 Act.

\section{Results}

\subsection{Long-Lasting Social Capital: OLS Results}

Table 1 reports the OLS for the entire sample. Regarding the number of associations registered during the period 1942-2015, our results show that each additional old township merged into the modern municipality (and therefore, each additional network of collective-action institutions) is related to more associations per capita. In model (3), in which we include the full set of covariates-district fixed-effects, geographic, climatic and additional population controlswe find that one more old township increases by 0.77 the number of associations per 1,000 inhabitants ( $4.4 \%$ of the sample mean).

Next, in Table 2 we analyze two different periods: associations registered during Franco's dictatorship and in its immediate aftermath (Panel A: 1942-1978), and associations registered during democracy (Panel B: 1979-2015). Our analysis by sub-periods reflects the different meaning of our dependent variable as a function of political system. In Panel A, results show that municipalities with more social capital in the past registered fewer associations under autocracy. In particular, focusing on model (3), we find that having one additional old township in a municipality decreases by 0.05 the number of associations per 1,000 inhabitants registered during 1942-1978 (4.2\% of the sample mean). 
Conversely, when considering the period in which the Constitution enshrined freedom of association, we find a positive impact. Our estimates from model (3) in Panel B show that 1 additional old township is associated with 0.8 additional associations per 1,000 inhabitants registered during $1979-2015$ (4.9\% of the sample mean).

\subsection{Long-Lasting Social Capital: IV Results}

As we have explained before, one potential problem with the OLS estimation is that our measure of social capital in the past-the number of old townships-might be endogenous. In order to address this we exploit a historical episode that generated exogenous variation in our variable of interest. We construct an instrumental variable, $z_{i}$, which is equal to the number of mergers that took place due to the application of the 1845 Act (i.e., the number of old townships that merged because they had $\leq 30$ householders in 1845).

In a first stage, we check the relevance of our instrument by testing its impact on the total number of old townships that form a current municipality, $x_{i}$ (our measure of social capital in the past):

$$
x_{i}=\alpha_{1}+\beta_{1} z_{i}+\gamma \text { covariates }_{i}+\lambda_{r} \text { district }_{r}+\epsilon_{1 i}
$$

In a second stage, we plug in the predicted values from equation (2) into the following equation, which captures the causal relationship of interest between contemporary social capital, $y_{i}$ and past social capital, $x_{i}$. By doing this we are using only the variation in $x_{i}$ that is generated by an exogenous factor, namely having $\leq 30$ householders in 1845 .

$$
y_{i}=\alpha_{2}+\beta_{2} \hat{x}_{i}+\gamma \text { covariates }_{i}+\lambda_{r} \text { district }_{r}+\epsilon_{2 i}
$$

Table 3 reports the results of the IV estimation. Panel A shows the first-stage coefficients which confirm the relevance and strength of our instrument: the numbers of mergers due to the application of the 1845 Act are positively associated with the total number of old townships that form a modern municipality and the F-statistic is large in all our specifications.

Regarding the second stage, the results for the autocratic period, shown in Panel B, confirm 
the negative findings of the OLS regression: an additional old township decreases in -0.08 the number of associations per 1,000 registered during this period (around 6.7\% of the sample mean). When taking all the organizations registered since 1979 (Panel C), we find that one additional old township increases in 0.9 the number of associations per 1,000 inhabitants $(5.5 \%$ of the sample mean). If we only analyze the period after which no previous authorization was required for registering an association, from 1997 until 2015 (Panel D), we find a slightly higher effect in relative terms: an increase in 1 old township adds 0.7 associations per 1,000 inhabitants, which represents $6.5 \%$ of the sample mean.

Our instrument is correlated with the past inclusion of small townships with a low population. This would threaten the validity of our instrument if current social capital were determined by the same factors that led to a low population count in 1845. For instance, this could be the case if some unobserved terrain feature both kept the population small and had a negative impact on social capital. In order to address this, we apply two different strategies.

First, we re-run the IV analysis with a restricted sample of municipalities. We keep only those municipalities in which mergers occurred due to the 1845 Act and those municipalities in which nothing happened between 1800 and 2015, and then we drop the ones in which the main town had 60 householders or more in 1845. Our restricted sample comprises 292 municipalities with similar population dynamics. ${ }^{12}$

The IV results with the restricted sample are shown in Table 4. Overall, the estimates are slightly larger than the ones found with the entire sample. One more township merged is associated with around 1.3 more associations per 1,000 inhabitants in the period 1979-2015 (about $6.2 \%$ of the sample mean). When we look at the 1997-2015 period, one more township merged is associated with 1.1 more associations per 1,000 inhabitants ( $8.2 \%$ of the sample mean). If we conduct the analysis with the associations registered during 1979-1996 only-during the early stages of democracy, but before the passing of the law that developed the constitutional right of association in Catalonia-we do not find a significant effect of the commons. These last results, shown in Table 13 in the appendix, confirm that the positive relationship between the

\footnotetext{
${ }^{12}$ The IV regressions with the restricted sample include the same covariates as the regressions with the entire sample, the only difference being that we include province fixed effects instead of district fixed effects because of the sample size.
} 
commons in the past and contemporary social capital is driven by the associations registered once the legislation developing freedom of association was fully in place in Catalonia.

\subsection{Results with Different Types of Associations}

In order to better understand the nature of the social capital we are analyzing, we focus on different categories of associations based on their main activities (cultural, civic rights, scientific knowledge and learning, pursing joint economic interests, health and social welfare, and environmental protection). We re-run the IV estimation, using the restricted sample to account for potential unobserved differences between the larger and smaller municipalities, and we limit the analysis to the period 1997-2015.

We only find statistically significant results when analyzing cultural and civic rights associations. These results are reported in Table 5. $\sqrt{13}^{13}$ Cultural and civic rights associations account for $45 \%$ and $12 \%$ of the total, respectively. Our results for cultural associations are shown in Panel A of Table 5. The estimated coefficient is $0.3-0.4$, meaning that one additional merger is associated with 0.3-0.4 more cultural associations per 1,000 inhabitants registered during the period 1997-2015, or about $5.4 \%$ of the sample mean. The persistent effect of social capital found seems to be mainly driven by the civic rights associations, as shown in Panel B. The magnitude of the effect is larger and precisely estimated: our results show that an increase in 1 additional old township is associated with 0.5 more civic rights associations per 1,000 inhabitants in the period $1997-2015$, or $25 \%$ of the sample mean.

These civic rights associations are typically neighborhood associations, which link people primarily based on their residence. In this sense they can be considered as representing the bonding type of social capital. However, neighborhood associations could be bridging in some other dimensions since, apart from the geographical criteria, they tend to be inclusive and group together individuals with different gender, age, and social class.

\footnotetext{
${ }^{13}$ Results for the remaining categories are shown in Table 14 in the appendix.
} 


\subsection{Long-Lasting Social Capital: RD Results}

Our second strategy to address the potential threat to the exclusion restriction of our IV is to apply a Regression Discontinuity Design. We exploit the discontinuity generated by the population threshold established in the 1845 Act to estimate the change in the number of old townships that form a modern municipality. In particular, we keep only those municipalities that had some merger during the implementation period of the 1845 Act (1845-1854) and those for which nothing happened since 1800 (i.e., the ones that have always been a single municipal entity). We also drop any new municipalities formed through division.

We focus on the time period and the type of associations that we have already shown to be more closely linked to the commons, namely, civic rights associations registered during the period 1997-2015. Our running variable in the RD regression is the population in 1845 of the township that eventually became the main town in the modern municipality. We first run the following regression:

$$
x_{i}=\alpha_{3}+\beta_{3} \operatorname{Over}_{30}+f(\text { pop } 1845)+\epsilon_{3 i}
$$

Table 6 reports these first-stage results in Panel A. We estimate that modern municipalities where the main town or village had more than 30 householders in 1845 comprise on average 1.7 fewer old townships than similar municipalities where the main town had 30 householders or less in 1845 and therefore were forced to merge with other townships. Figure 3 (upper panel) shows the corresponding graph in which we can appreciate that the discontinuity when crossing the threshold is clearly visible.

The underlying identifying assumption is the following: if we expect everything else that could affect social capital today to behave smoothly across this threshold, then, if we find a discontinuity in contemporary associations at this same threshold, we can attribute it to those mergers. Because we are comparing municipalities where the main town had a very similar population size in 1845 this RD strategy overcomes the validity threats of our IV estimation.

Figure 4 explores the smoothness of several relevant variables at this same threshold. We first examine whether there is a discontinuity in the resulting population size in 1845 and in the total land area of the newly formed municipalities. The lack of discontinuity speaks in favor 
of our hypothesis and rules out the alternative hypothesis of a simple 'group effect', i.e., that the amalgamation of more individuals and a greater total land area is what causes the increase in social capital ${ }^{14}$ We are comparing municipalities with very similar population and land size and the only thing that differs among them is the number of townships (or networks) that merged.

In the lower panel of Figure 4 we analyze the smoothness of the literacy rates in 1860 and 1900, respectively. We view these variables as proxies of local public-good provisions, since primary education was a municipal responsibility until the beginning of the twentieth century ${ }^{15}$ Again, we find no discontinuity at the 30-householders threshold, neither a decade nor fifty years after the merging process was completed ${ }^{16}$ We interpret this as suggestive evidence that there were no significant changes in local governance that could have fostered an increase in social capital in the municipality. In Section 7.2 we analyze some present-day institutional differences—by looking at government transparency and citizen participation—and again find no evidence of differences in contemporary local governance.

An additional identifying assumption is that there is no manipulation of the forcing variable (householders in the main town of the modern municipality in 1845). We follow McCrary (2008) density test and find no evidence of discontinuity at the threshold. The results of this test are shown in Table 7 and its corresponding Figure 5. Regardless of the bandwidth used, we can never reject that the discontinuity estimate is equal to zero at a $10 \%$ significance level or lower.

Next, we apply the same regression framework as in equation (4) but use the number of civic rights associations per capita registered in the period 1997-2015 as the dependent vari-

\footnotetext{
${ }^{14}$ The RD coefficient and standard error for the regression on population in 1845 is -80.6 and 58.6, respectively. For the land size of the modern municipality these figures are -5.5 and 9.2, respectively.

${ }^{15}$ In 1902 the central government began to pay schoolteachers directly.

${ }^{16}$ The RD coefficients and standard errors (in parentheses) for literacy rates in 1860 are $0.007(0.013)$ and 0.014 (0.039), respectively.
} 
able:17

$$
y_{i}=\alpha_{4}+\beta_{4} \text { Over } 30_{i}+f(\text { pop } 1845)+\epsilon_{4 i}
$$

Results for $\beta_{4}$ are reported in Panel B of Table 6, and the discontinuity is shown in a graph in Figure 3 (lower panel). Overall, our results show that those municipalities where the main towns had more than 30 householders in 1845 (and therefore had fewer mergers) have 2.7 fewer civic rights associations per 1,000 inhabitants registered in the period 1997-2015.

We can combine these estimates to obtain the treatment effect:

$$
\rho=\frac{\beta_{4}}{\beta_{3}}==\frac{-2.7}{-1.7}=1.5
$$

or equivalently, run a 2SLS estimation, in which we use the predicted values of $x_{i}$ from equation (4) and plug them into the causal relationship of interest:

$$
y_{i}=\gamma+\rho \hat{x}_{i}+f(p o p 1845)+f(p o p 2015)+u_{i}
$$

The estimated coefficient is reported in Panel C of Table 6. It shows that for those municipalities that resulted from a merger because their main township had 30 householders or less in 1845, 1 additional merger is associated with 1.5 more associations per 1,000 inhabitants (approximately $75 \%$ of the sample mean). This effect is larger than the one estimated using the IV, and confirms the long-lasting effect of the commons in today's density of neighborhood associations.

As a robustness check, Figure 6 shows similar first-stage and reduced-form graphs for a smaller bandwidth of 25 householders on each side of the threshold. 18 We also explore in

\footnotetext{
${ }^{17}$ To account for current population, we first regress $y_{i}$ on a second-order polynomial of 2015 population, and use the predicted residuals as the dependent variable in equation 4. Population in 2015 is winsorized at 5\% to account for outliers. In all the RD regressions, we address the fact that the forcing variable is discrete, and consequently the regression is prone to specification error, by clustering the standard errors by householders (Lee and Card 2008).

${ }^{18}$ The RD coefficient and standard error (in parenthesis) in the upper panel is -1.34 (0.75) and, $-2.46(0.94)$ in the below panel $(n=270)$.
} 
Figure 7 a placebo RD at the 100-inhabitants threshold (instead of 30 householders) and, reassuringly, find no discontinuity at this different threshold 19

\subsection{Impact of Social Capital on Economic Development: IV Results}

Our next goal is to analyze the impact of social capital on economic development. Social capital is considered the missing ingredient in explaining the persistence of differences in economic development. Hall and Jones (1999) referred to the concept of social infrastructure as providing "an environment that supports productive activities and encourages capital accumulation, skill acquisition, invention, and technology transfer".

This empirical analysis is challenging mainly for two reasons. First, there might be reverse causality, since richer municipalities might develop more social capital rather than the other way around. Second, omitted variables (e.g., better institutions which might foster both growth and social capital) could bias the results.

We address these endogeneity issues applying an IV strategy. Our instrument for contemporary social capital-which has been validated in the previous sections-is the number of mergers as a consequence of having $\leq 30$ householders in 1845. We measure economic development as the income-tax base per capita, which has the advantage of being available for municipalities with more than 1,000 inhabitants (around 460 municipalities). Information on GDP is only available for municipalities with more than 5,000 inhabitants (slightly over 200).

We run a first-stage regression similar to the one looking at the persistence of social capital:

$$
x_{i}=\alpha_{1}+\beta_{1} z_{i}+\text { rcovariates }_{i}+\lambda_{r} \text { Province }_{r}+\epsilon_{1 i}
$$

where $x_{i}$ is our previous measure of social capital, i.e., associations per capita. Due to sample size limitations, we include Province $r$, province fixed effects, instead of district fixed effects, and we use a large subset of our climatic variables ${ }^{20}$ Also, we cluster the standard errors at

\footnotetext{
${ }^{19}$ The RD coefficient and standard error (in parenthesis) in the upper panel is -0.28 (1.04) and, -0.81 (1.71) in the below panel.

${ }^{20}$ We no longer include distance to a river, standard deviation of temperature (which is highly correlated with distance to the sea) and standard deviation of rainfall (which is highly correlated to elevation).
} 
the district level to account for potential residential sorting across adjacent municipalities (e.g., richer individuals might choose to live in the same local set of municipalities within the same district).

In the second stage, we plug the predicted values from equation (7) into the following equation, which captures the causal relationship of interest between contemporary economic development, $y_{i}$, and social capital, using only the variation in $x_{i}$ generated by the 1845 Act:

$$
y_{i}=\alpha_{2}+\beta_{2} \hat{x}_{i}+\gamma \text { covariates }{ }_{i}+\lambda_{r} \text { Province }_{r}+\epsilon_{2 i}
$$

We first run the IV regression only with population, geographic and climatic controls, and subsequently include known drivers of economic development: human capital, innovation, roads and public infrastructure, financial capital and police force size. We also control for tourism activity in the municipality, in case a higher number of old townships-and their correspondent historical sites-attracts more tourists, which would violate the exclusion restriction. All these variables are measured at the municipal level for the year 2015 or the closest available year.

Table 8 and 9 show the results. In Table 8 social capital is measured as all associations registered during the period 1997-2015, while Table 9 focuses only on civic rights associations registered in the same period (per 1,000 inhabitants). In both cases, Panel A shows strong and significant first stage results, meaning that the number of mergers due to the 1845 Act is a powerful predictor of the density of associations in the last two decades. In Panel B we present the IV results, which are again statistically significant and remarkably stable throughout the specifications. For all association types, focusing on Table 8 , an increase of 1 is associated with an increase of around 500 euros in the income-tax base per capita. The effect is larger when we analyze civic rights associations only (Table 9): an increase of 1 in the number of civic rights associations per 1,000 inhabitants is associated with an increase of around 1,400 euros in the income-tax base per capita ${ }^{21}$

We analyze the impact of social capital on the economic development in previous years. Our explanatory variable is the number of civic rights associations per 1,000 inhabitants reg-

\footnotetext{
${ }^{21}$ Table 15 in the appendix shows the reduced-form results.
} 
istered during the period 1997-2005 in Table 16, and 1997-2010 in Table 17 in the appendix. The dependent variable is the income-tax base per capita in 2005 and 2010, respectively ${ }^{22}$ Our results suggest that the positive effects of social capital on economic development are concentrated during the first years in which associational rights were defined, and that they would diminish over time.

\section{Additional Results}

\subsection{Alternative Measures of Social Capital}

So far, we have measured current social capital as the density of the associative network, which relates closely to our measure of social capital in the past: the networks that arose around the commons. However, social capital is a broad concept that does not only encompass networks but also shared values and beliefs, as well as pro-social behavior. In this section, we explore alternative definitions of social capital and analyze whether they are also related to the commons.

\subsubsection{Perceptions of Civic Behavior, Social Interaction, Resident Engagement}

We use the Public Safety Survey for Catalonia, which was primarily designed to collect individuals' experiences of and opinions on crime, policing and security. Conveniently for us, the 2012 edition introduced a module regarding individual perceptions of good citizenship, and the degree to which neighbors connect to each other and are involved in community issues. These are the three measures we consider as proxies of social capital. In fact, one could also consider these variables as a measure of pro-social behavior, which is a slightly different facet of social capital. ${ }^{23}$ The survey is conducted at the individual level; we aggregate the information at the

\footnotetext{
${ }^{22}$ All covariates are computed at the closest available year in each table.

${ }^{23}$ The three specific questions are the following: "On a scale from 0 (none) to 10 (a lot), how do you value the level of good citizenship in your municipality?"; "Regarding the people in your neighborhood/municipality, how often do you interact with them in a scale from 0 (I do not interact with anybody) to 10 (I have relationships with many people)"; "Regarding the following problems: impoliteness of your neighbors, bad shape of urban
} 
municipal level and end up with a sample of 104 municipalities.

In Table 18 in the appendix we present basic univariate regressions of these three proxies of social capital on our main variable of social capital—number of associations per capita. We limit our analysis to the period comprised between the passing of the Law on Associations Act in 1997 in Catalonia and the survey year (2012), and distinguish between total associations, civic rights associations only, and cultural associations only. Regardless of the definition of associational activity we use, we find statistically significant and positive correlations between these variables.

Next, we run our IV regressions using these three proxies of social capital as outcome variables. Results are shown in Table 10, and point again to a positive relationship between the experiences of collaboration around the commons in the past and today's pro-social behavior at the municipal level.

\subsubsection{Blood Donations}

Blood donations are considered a measure of individual altruism but could also be conceptualized as a social phenomenon embedded in the community. We collected data from the "Banc de Sang i Teixits" (Blood and Tissue Bank) of the Catalan Health Department. This data has one key limitation for our analysis: it provides the number of donations collected in each municipality regardless of donor origin. This can be problematic since not all municipalities provide this service and individuals are therefore forced to travel to other towns if they want to donate blood. Figure 8 in the appendix shows the reduced-form RD graphs of an index of blood donation at the municipal level (averaged for the period 2007-2015, and for 2015 only). We do not find any significant discontinuity at the 30-householder threshold in 1845 . However, because of the data limitations explained, we interpret these results with caution.

amenities, noise, uncleanliness, presence of drug-users or drug-dealers, disruptive youth, prostitutes, homeless people and beggars; how do you value your neighbors' behavior on a scale from 0 (they don't do anything about it) to 10 (they do a lot)?". 


\subsection{Government Transparency and Citizen Participation}

Government transparency helps citizens to make informed decisions and hold their representatives accountable, and in this sense it allows good governance. We attempt to gauge whether there is an impact of social capital on the quality of local governance by constructing a transparency index at the municipal level.

For this purpose, we use data collected by the Pi i Sunyer Foundation for year 2017. We select 82 questions that deal with different dimensions of transparency, for instance proactive disclosure of personal and financial information, and assessment of public services, and construct an index which ranges between 0 (no transparency at all) to 1 (maximum transparency). Additionally, we focus on three of these questions to construct an index of citizen participation, initiated by the local government ${ }^{24}$

The reduced-form RD graphs for these two variables are shown in Figure 9 in the appendix. We do not find any significant change in neither the transparency index nor the citizen participation index when crossing the 30-householders threshold. This suggests that the higher cooperation and trust developed at the citizens' level due to the former presence of the commons does not lead to more transparent governance and citizen engagement. We thus hypothesize that the persistence of social capital over time, long after the commons disappeared, is due to its cultural transmission across generations rather than due to alternative institutional channels at the local level.

\section{Conclusions}

In this project we aim to understand the historical origins of social capital, to document its long-term persistence as well as its effects on economic development by focusing on the legacy

\footnotetext{
${ }^{24}$ Regarding the transparency index, its average is 0.50 , standard deviation 0.13 , and minimum and maximum values 0.13 and 0.93 , respectively. As for the citizen participation index it varies between 0 and 1 , has a mean o 0.52 and a standard deviation of 0.31 . The three questions we use to measure citizen engagement are: (1) "does the local government identify channels for citizen participation?"; (2) "is there information regarding the channels for citizen participation?"; and (3) "are there spaces (websites, brochures, etc.) dedicated to citizen engagement?".
} 
of the commons in a Spanish region (Catalonia). Common goods are resources (forests, pasture, irrigation systems, etc.) that are used collectively according to certain rules. In early medieval times, common goods were granted to townships and were managed collectively by the local residents, a fact which enabled the establishment of institutions for collective action and self-government. Common goods persisted until the second half of the nineteenth century, when some modernizing reforms, especially the Disentailment Act of 1855, contributed to their disappearance. We argue that the experience of cooperation and mutual trust among villagers, repeated over centuries, increased the stock of social capital in each local community.

In 1845, a law forced small municipalities to merge with others. We exploit the exogenous variation that this law generated in the number of mergers (i.e., the number of cooperative networks that merged) that formed each modern municipality. Our results show that municipalities composed of more townships currently have a denser network of voluntary associations. We show that the persistence of social capital is mainly driven by neighborhood associations that uphold and promote the civic rights of local communities, a type of association which proliferated throughout Catalan municipalities since 1997, once the regional parliament had defined the rights and rules governing associations. We also explore alternative measures of social capital, and the mechanisms behind its persistence.

This exercise allows us to obtain a valid instrument for social capital to identify its causal impact on economic development. We find that social capital measured as associational life has a positive impact on economic development at the municipal level. With this study, we aim to contribute to the literature on social capital by providing a comprehensive theory of its determinants and exploiting a convincing source of exogenous variation.

Even though we focus our study on the legacy of the commons in a Spanish region, we believe that our results can be generalized to other contexts. After all, the commons are an ancient institution which managed to survive for a long time in rural and small towns in most cases, and was widespread around the world, especially in pre-industrial Europe. 


\section{REFERENCES}

Beltrán-Tapia, Francisco J. (2012), “Commons, social capital, and the emergence of agricultural cooperatives in early twentieth century Spain", European Review of Economic History, 16: 511-528.

Beltrán-Tapia, Francisco J. (2013), “Enclosing literacy? Common lands and human capital in Spain, 1860-1930", Journal of Institutional Economics, 9(4): 491-515.

Beltrán-Tapia, Francisco J. (2015a), "Commons and the standard of living debate in Spain, 1860-1930", Cliometrica, 9(1): 27-48.

Beltrán-Tapia, Francisco J. (2015b), "'Goth and Vandals' or 'Civilised' peasants? Common lands and agricultural productivity in Spain, 1900-1930", Social Science History, 39(2): 217-252.

Beltrán-Tapia, Francisco J. (2015c), "Social and evironmental filters to market incentives: Common land persistence in 19th century Spain", Journal of Agrarian Change, 15(2): 239-260.

Beltrán-Tapia, Francisco J. (2016), "Common lands and economic development in Spain", Revista de Historia Económica - Journal of Iberian and Latin American Economic History, 34(1): 111133.

Blesse, Sebastian and Thushyanthan Baskaran (2016), "Do municipal mergers reduce costs? Evidence from a German federal state", Regional Science and Urban Economics, 59: 5474 .

Blom-Hansen, Jens, Kurt Houlberg, Soren Serritzlew, and Daniel Treisman (2026), “Jurisdiction Size and Local Government Policy Expenditure: Assessing the Effect of Municipal Amalgamation", American Political Science Review, 110(4): 812-831.

Boix, Carles, and Daniel N. Posner (1996), "Making Social Capital Work: A Review of Robert Putnam's Making Democracy Work: Civic Traditions in Modern Italy", Harvard University Paper No. 96-4.

Brenan, Gerald (1990), The Spanish Labyrinth. Canto Ed.

Buggle, Johannes C., and Ruben Durante (2017), “Climate Risk, Cooperation and the CoEvolution of Culture and Institutions", Working Paper.

Buonanno, Paolo, Daniel Montolio, and Paolo Vanin (2009), “Does Social Capital Reduce 
Crime?", Journal of Law and Economics, 52(1): 145-170.

Burgueño, Jesús, and Ferran Lasso de la Vega (2002), Història del mapa municipal de Catalunya. Generalitat de Catalunya, Departament de Governació i relacions Institucionals, Direcció General d'Administració Local.

Busqueta, Joan, and Enric Vicedo (1996), Béns Comunals als Pä̈sos Catalans i a l'Europa Contemporània. Institut d'Estudis Ilerdencs.

De Moor, Tine (2008), “The Silent Revolution: A New Perspective on the Emergence of Commons, Guilds, and Other Forms of Corporate Collective Action in Western Europe", IRSH 53S: 179-212.

Dirección General del Instituto Geográfico y Estadístico (1922). Censo general de la población de España (various years). Madrid.

Durlauf, Steven N. (2002), "On the Empirics of Social Capital", The Economic Journal, 112(483): F459-F479.

Font i Garolera, Jaume (1993), "La formació històrica de la xarxa de carreteres a Catalunya", Estudi General 13: 127-152.

Font i Rius, Josep Maria (1985), “Estudis sobre els drets i institucions locals en la Catalunya medieval." Universitat de Barcelona.

Guiso, Luigi, Paola Sapienza, and Luigi Zingales (2011), "Civic Capital as the Missing Link", Handbook of Social Economics.

Guiso, Luigi, Paola Sapienza, and Luigi Zingales (2016), "Long-term persistence”, Journal of the European Economic Association, 14(6): 1401-1436.

Hall, Robert E., and Charles I. Jones (1999), "Why Do Some Countries Produce So Much More Output Per Worker Than Others", Quarterly Journal of Economics, 114(1): 83-116.

Jefatura Superior de Estadística (1926). Anuario estadístico de España (various years). Madrid.

Kagay, Donald J. (1994), The Usatges of Barcelona: The Fundamental Law of Catalonia.

Knack, Stephen, and Philip Keefer (1997), “Does Social Capital Have an Economic Payoff? A Cross-Country Investigation", Quarterly Journal of Economics, 112(4): 1251-1288.

Lee, David S., and David Card (2008), "Regression discontinuity inference with specification error", Journal of Econometrics, 142(2): 655-674. 
McCrary, Justin (2008), "Manipulation of the running variable in the regression discontinuity design: A density test", Journal of Econometrics, 142(2): 698-714.

Nunn, Nathan (2012), "Culture and the Historical Process", Economic History of Developing Regions, 27(S1): 108-126.

Ostrom, Elinor (1990), Governing the Commons: The Evolution of Institutions for Collective Action. Cambridge University Press, Cambridge.

Padró i Miquel, Gerard, Nacy Qian, Yiqing Xu, and Yang Yao (2015), "Making Democracy Work: Culture, Social Capital and Elections in China", NBER Working Paper No. 21058.

Putnam, Robert D. (1993), Making Democracy Work. Princeton University Press, Princeton NJ.

Reingewertz, Yaniv (2012), “Do municipal amalgamations work? Evidence from municipalities in Israel", Journal of Urban Economics 72(2-3): 240-251.

Satyanat, Shanker, Nico Voigtländer, and Hans-Joachim Voth (2017), “Bowling for Fascism: Social Capital and the Rise of the Nazi Party", Journal of Political Economy 125(2): 478-526.

Tabellini, Guido (2010), "Culture and institutions: economic development in the regions of Europe", Journal of the European Economic Association, 8(4): 677-716.

Viñas, Jordi, Xavier Català, Carles Fañanás, et al. (2016), Béns comunals. Un sistema d'organització del passat per gestionar el present. Grup de Treball sobre Temes i Béns Comunals del Pallars Sobirà. Fundació del Món Rural, i IDAPA. 


\section{Tables and Figures}

Table 1: OLS Results. Long-lasting Effects on Voluntary Associations 1942-2015

\begin{tabular}{lccc}
\hline \hline Mean (St.Dev.) Dep. Var. & \multicolumn{3}{c}{$17.5(12.9)$} \\
\hline Number of Old Townships & $(1)$ & $(2)$ & $(3)$ \\
& $0.38^{*}$ & $0.72^{* * *}$ & $0.77^{* * *}$ \\
& $(0.202)$ & $(0.192)$ & $(0.189)$ \\
\hline Adj- $R^{2}$ & 0.13 & 0.28 & 0.29 \\
Observations & 913 & 913 & 913 \\
\hline Judicial District FE & Yes & Yes & Yes \\
Geographic \& climatic controls & No & Yes & Yes \\
Additional population controls & No & No & Yes \\
\hline \hline
\end{tabular}

The dependent variable is the number of associations registered during the period 1942-2015 in a given municipality, divided by the population in 2015 and multiplied by 1,000. All models include population size measured in 2015 and 1845, and municipal land area. Geographic and climatic controls include elevation, ruggedness, distance to the sea and to a river, mean and standard deviation of rainfall, and mean and standard deviation of temperatures. Additional population controls include population squared both in 1845 and in 2015 and an indicator variable that takes the value 1 if a municipality has more than 100,000 inhabitants in 2015. Robust standard errors in parentheses. * $p<0.10,{ }^{* *} p<0.05,{ }^{* * *} p<0.01$. 


\section{Table 2: OLS Results. Long-lasting Effects on Voluntary Associations by Sub-Periods}

\begin{tabular}{|c|c|c|c|}
\hline \multicolumn{4}{|c|}{ Panel A: 1942-1978 } \\
\hline & (1) & (2) & (3) \\
\hline Mean (St.Dev.) Dep. Var. & \multicolumn{3}{|c|}{$1.2(2.9)$} \\
\hline \multirow[t]{2}{*}{ Number of Old Townships } & $-0.07^{* *}$ & $-0.06^{* *}$ & $-0.05^{*}$ \\
\hline & $(0.026)$ & $(0.026)$ & $(0.027)$ \\
\hline Adj- $R^{2}$ & 0.12 & 0.13 & 0.13 \\
\hline Observations & 909 & 909 & 909 \\
\hline \multicolumn{4}{|c|}{ Panel B: 1979-2015 } \\
\hline Mean (St.Dev.) Dep. Var. & \multicolumn{3}{|c|}{$16.4(12.3)$} \\
\hline \multirow[t]{2}{*}{ Number of Old Townships } & $0.46^{* *}$ & $0.78^{* * *}$ & $0.82^{* * *}$ \\
\hline & $(0.200)$ & $(0.192)$ & $(0.189)$ \\
\hline Adj- $R^{2}$ & 0.14 & 0.27 & 0.28 \\
\hline Observations & 913 & 913 & 913 \\
\hline Judicial District FE & Yes & Yes & Yes \\
\hline Geographic \& climatic controls & No & Yes & Yes \\
\hline Additional population controls & No & No & Yes \\
\hline
\end{tabular}

The dependent variable is the number of associations registered during 19421978 in Panel A and during 1979-2015 in Panel B in a given municipality, divided by the population in 1978 and multiplied by 1,000. All models include population size measured in 1978 in Panel A and 2015 in Panel B and 1845, and municipal land area. Geographic and climatic controls include elevation, ruggedness, distance to the sea and to a river, mean and standard deviation of rainfall, and mean and standard deviation of temperatures. Additional population controls include population squared both in 1845 and in 1978 (Panel A) or 2015 (Panel B) and an indicator variable that takes the value 1 if a municipality has more than 100,000 inhabitants in 2015. Robust standard errors in parentheses. ${ }^{*} p<0.10,{ }^{* *} p<0.05,{ }^{* * *} p<0.01$. 
Table 3: IV Results. Long-lasting Effects on Voluntary Associations by Sub-Periods

\begin{tabular}{|c|c|c|c|}
\hline \multicolumn{4}{|c|}{ Panel A: First-Stage Results } \\
\hline \multirow{2}{*}{$\begin{array}{l}\text { Mean (St.Dev.) Dep. Var. } \\
\text { N. Mergers Law } 1845\end{array}$} & \multicolumn{3}{|c|}{$2.3(2.7)$} \\
\hline & $1.05^{* * *}$ & $1.04^{* * *}$ & $1.05^{* * *}$ \\
\hline & $(0.041)$ & $(0.039)$ & $(0.038)$ \\
\hline F-statistic & 651.8 & 724.1 & 754.5 \\
\hline \multicolumn{4}{|c|}{ Panel B: Second-Stage Results (1942-1978) } \\
\hline Mean (St.Dev.) Dep. Var. & \multicolumn{3}{|c|}{$1.2(2.9)$} \\
\hline \multirow[t]{2}{*}{ Number of Old Townships } & $-0.07^{* *}$ & $-0.08^{* *}$ & $-0.08^{* *}$ \\
\hline & $(0.033)$ & $(0.034)$ & $(0.034)$ \\
\hline Centered- $R^{2}$ & 0.17 & 0.19 & 0.19 \\
\hline Observations & 913 & 913 & 913 \\
\hline \multicolumn{4}{|c|}{ Panel C: Second-Stage Results (1979-2015) } \\
\hline Mean (St.Dev.) Dep. Var. & \multicolumn{3}{|c|}{$16.4(12.3)$} \\
\hline \multirow[t]{2}{*}{ Number of Old Townships } & $0.86^{* * *}$ & $0.93^{* * *}$ & $0.91^{* * *}$ \\
\hline & $(0.261)$ & $(0.246)$ & $(0.240)$ \\
\hline Centered- $R^{2}$ & 0.18 & 0.32 & 0.33 \\
\hline \multicolumn{4}{|c|}{ Panel D: Second-Stage Results (1997-2015) } \\
\hline Mean (St.Dev.) Dep. Var. & \multicolumn{3}{|c|}{$10.2(8.6)$} \\
\hline \multirow[t]{2}{*}{ Number of Old Townships } & $0.66^{* * *}$ & $0.67^{* * *}$ & $0.65^{* * *}$ \\
\hline & $(0.199)$ & $(0.190)$ & $(0.186)$ \\
\hline Centered- $R^{2}$ & 0.13 & 0.21 & 0.22 \\
\hline Observations & 913 & 913 & 913 \\
\hline Judicial District FE & Yes & Yes & Yes \\
\hline Geographic \& climatic controls & No & Yes & Yes \\
\hline Additional population controls & No & No & Yes \\
\hline \multicolumn{4}{|c|}{$\begin{array}{l}\text { All models include population size measured in } 1978 \text { (in Panel B) and } 2015 \text { (in } \\
\text { Panel C and D) and 1845, and municipal land area. Geographic and climatic } \\
\text { controls include elevation, ruggedness, distance to the sea and to a river, mean } \\
\text { and standard deviation of rainfall, and mean and standard deviation of tem- } \\
\text { peratures. Additional population controls include population squared both in } \\
1845 \text { and in } 1978 / 2015 \text { and an indicator variable that takes the value } 1 \text { if a mu- } \\
\text { nicipality has more than } 100,000 \text { inhabitants in } 2015 \text {. Robust standard errors } \\
\text { in parentheses. }{ }^{*} p<0.10,{ }^{* *} p<0.05,{ }^{* * *} p<0.01 \text {. }\end{array}$} \\
\hline
\end{tabular}


Table 4: IV Results with Restricted Sample. Long-lasting Effects on Voluntary Associations 1979-2015

\begin{tabular}{|c|c|c|c|}
\hline \multicolumn{4}{|c|}{ Panel A: First-Stage Results } \\
\hline \multirow{2}{*}{$\begin{array}{l}\text { Mean (St.Dev.) Dep. Var. } \\
\text { N. Mergers Law } 1845\end{array}$} & \multicolumn{3}{|c|}{$3.1(3.3)$} \\
\hline & $0.94^{* * *}$ & $0.93^{* * *}$ & $0.93^{* * *}$ \\
\hline & $(0.052)$ & $(0.053)$ & $(0.056)$ \\
\hline F-statistic & 330.8 & 311.0 & 279.3 \\
\hline \multicolumn{4}{|c|}{ Panel B: Second-Stage Results (1979-2015) } \\
\hline Mean (St.Dev.) Dep. Var. & \multicolumn{3}{|c|}{$21(15.5)$} \\
\hline \multirow[t]{2}{*}{ Number of Old Townships } & $1.29^{* * *}$ & $1.30^{* * *}$ & $1.29^{* * *}$ \\
\hline & $(0.337)$ & $(0.332)$ & $(0.328)$ \\
\hline Centered- $R^{2}$ & 0.11 & 0.21 & 0.25 \\
\hline \multicolumn{4}{|c|}{ Panel C: Second-Stage Results (1997-2015) } \\
\hline Mean (St.Dev.) Dep. Var. & \multicolumn{3}{|c|}{$13.1(11.4)$} \\
\hline \multirow[t]{2}{*}{ Number of Old Townships } & $1.11^{* * *}$ & $1.03^{* * *}$ & $1.08^{* * *}$ \\
\hline & $(0.295)$ & $(0.278)$ & $(0.288)$ \\
\hline Centered- $R^{2}$ & 0.08 & 0.15 & 0.18 \\
\hline Observations & 292 & 292 & 292 \\
\hline Province FE & Yes & Yes & Yes \\
\hline Geographic \& climatic controls & No & Yes & Yes \\
\hline Additional population controls & No & No & Yes \\
\hline \multicolumn{4}{|c|}{$\begin{array}{l}\text { All models include population size measured in } 2015 \text { and } 1845 \text {, and municipal } \\
\text { land area. Geographic and climatic controls include elevation, ruggedness, } \\
\text { distance to the sea and to a river, mean and standard deviation of rainfall, and } \\
\text { mean and standard deviation of temperatures. Additional population controls } \\
\text { include population squared both in } 1845 \text { and in } 2015 \text {. Robust standard errors } \\
\text { in parentheses. }{ }^{*} p<0.10,{ }^{* *} p<0.05,{ }^{* * *} p<0.01 \text {. }\end{array}$} \\
\hline
\end{tabular}


Table 5: IV Results by Types of Associations, with Restricted Sample, 1997-2015

\begin{tabular}{lccc}
\hline \hline \multicolumn{4}{c}{ Panel A: Second-Stage Results Cultural Associations } \\
\hline Mean (St.Dev.) Dep. Var. & \multicolumn{3}{c}{$6(6.9)$} \\
\hline Number of Old Townships & $0.28^{*}$ & $0.30^{*}$ & $0.37^{* *}$ \\
& $(0.166)$ & $(0.168)$ & $(0.166)$ \\
\hline Centered- $R^{2}$ & 0.06 & 0.08 & 0.10 \\
\hline \hline \multicolumn{1}{c}{ Panel B: Second-Stage Results Civic Rights Associations } \\
\hline Mean (St.Dev.) Dep. Var. & \multicolumn{3}{c}{$2(3.4)$} \\
\hline Number of Old Townships & $0.50^{* * *}$ & $0.46^{* * *}$ & $0.47^{* * *}$ \\
& $(0.125)$ & $(0.123)$ & $(0.130)$ \\
\hline Centered- $R^{2}$ & 0.23 & 0.27 & 0.27 \\
Observations & 292 & 292 & 292 \\
\hline Province FE & Yes & Yes & Yes \\
Geographic \& climatic controls & No & Yes & Yes \\
Additional population controls & No & No & Yes \\
\hline \hline
\end{tabular}

All models include population size measured in 2015 and 1845, and municipal land area. Geographic and climatic controls include elevation, ruggedness, distance to the sea and to a river, mean and standard deviation of rainfall, and mean and standard deviation of temperatures. Additional population controls include population squared both in 1845 and in 2015. Robust standard errors in parentheses. ${ }^{*} p<0.10,{ }^{* *} p<0.05,{ }^{* * *} p<0.01$. 
Table 6: RD Results. Long-lasting Effects on Civic Rights Associations During 1997-2015

\begin{tabular}{lc}
\hline \hline \multicolumn{2}{c}{ Panel A: First-Stage Results } \\
\hline$>30$ householders in 1845 & $-1.7^{* *}$ \\
& $(0.85)$ \\
\hline \hline \multicolumn{2}{c}{ Panel B: Reduced-Form Results } \\
\hline P0 householders in 1845 & $-2.7^{* * *}$ \\
& $(0.90)$ \\
\hline \hline Number of Old Townships & $1.5^{*}$ \\
& $(0.85)$ \\
\hline Bandwidth(householders) & 30 \\
Observations & 292 \\
\hline \hline
\end{tabular}

The unit of observation is the capital of the modern municipality. The model includes controls for population and population squared in 1845 , a dummy variable that takes the value 1 if population is higher than the threshold ( 30 householders), and the interaction terms between population in 1845 (and its squared) with the dummy variable. Population in 2015 is winsorized at the 0.05 level. Standard errors in parentheses are clustered at the householders level in 1845 . ${ }^{*} p<0.10$, ${ }^{* *} p<0.05,{ }^{* * *} p<0.01$.

\section{Table 7: McCrary Density Test of Manipulation of the Running Variable}

\begin{tabular}{|l|c|c|c|}
\hline & Default bandwidth (11.4) & Bandwidth=9 & Bandwidth=14 \\
\hline Discontinuity estimate & 0.32 & 0.27 & 0.34 \\
& $(0.35)$ & $(0.40)$ & $(0.32)$ \\
\hline
\end{tabular}

These results are obtained using the Stata command DCdensity which followed McCrary (2008). The discontinuity estimate is expressed as the log difference in height. Standard errors in parentheses. 
Table 8: IV Results. Income Tax Base per Capita 2015 with All Associations (1997-2015)

\begin{tabular}{|c|c|c|c|c|c|c|c|}
\hline \multicolumn{8}{|c|}{ Panel A: First-Stage Results } \\
\hline \multirow{3}{*}{$\begin{array}{l}\text { Mean (St.Dev.) Dependent Var. } \\
\text { N. Mergers Law } 1845\end{array}$} & \multicolumn{6}{|c|}{$6.8(3)$} & \multirow{3}{*}{$\begin{array}{l}0.44^{* * *} \\
(0.070)\end{array}$} \\
\hline & $0.44^{* * *}$ & $0.44^{* * *}$ & $0.44^{* * *}$ & $0.43^{* * *}$ & $0.44^{* * *}$ & $0.44^{* * *}$ & \\
\hline & $(0.063)$ & $(0.063)$ & $(0.063)$ & $(0.062)$ & $(0.063)$ & $(0.068)$ & \\
\hline F-statistic & 48.5 & 49.5 & 48 & 49.1 & 48.7 & 41.2 & 40.7 \\
\hline \multicolumn{8}{|c|}{ Panel B: Second-Stage Results } \\
\hline Mean (St.Dev.) Dependent Var. & & & 20,016 & $5(3,846)$ & & & \\
\hline \multirow[t]{2}{*}{ All assoc pc (97-15) } & $498.6^{* *}$ & $514.2^{* * *}$ & $531.6^{* * *}$ & $557.4^{* * *}$ & $534.1^{* * *}$ & $544.4^{* * *}$ & $500.5^{* * *}$ \\
\hline & $(213.9)$ & $(156.2)$ & $(159.5)$ & $(156.7)$ & $(144.3)$ & $(157.8)$ & $(150.3)$ \\
\hline Human Capital & & Yes & Yes & Yes & Yes & Yes & Yes \\
\hline Innovation & & & Yes & Yes & Yes & Yes & Yes \\
\hline Roads \& Public Infrastructure & & & & Yes & Yes & Yes & Yes \\
\hline Financial Capital & & & & & Yes & Yes & Yes \\
\hline Police Forces & & & & & & Yes & Yes \\
\hline Tourism & & & & & & & Yes \\
\hline Observations & 434 & 434 & 434 & 434 & 434 & 434 & 434 \\
\hline Centered- $R^{2}$ & 0.22 & 0.42 & 0.41 & 0.40 & 0.42 & 0.43 & 0.45 \\
\hline
\end{tabular}

All models include a second-order polynomial function of the population measured in 2015 and 1845, municipal land area, elevation, ruggedness, distance to the sea, mean rainfall, mean temperature, an indicator variable that takes the value 1 if a municipality has more than 100,000 inhabitants, and province fixed effects. Additional controls include the percentage of citizens with secondary or college education in 2001, patents per 1,000 inhabitants in 2015, road density in 1990, sports facilities per 1,000 inhabitants in 2016, and libraries per 1,000 inhabitants in 2014, bank branches per 1,000 inhabitants in 2002, local police officers per 1,000 inhabitants in 2015, and hotels per 1,000 inhabitants in 2015. Clustered standard errors at the district level in parentheses. ${ }^{*} p<0.10,{ }^{* *} p<0.05,{ }^{* * *} p<0.01$. 
Table 9: IV Results. Income Tax Base per Capita 2015 with Civic Rights Associations (19972015)

\begin{tabular}{|c|c|c|c|c|c|c|c|}
\hline \multicolumn{8}{|c|}{ Panel A: First-Stage Results } \\
\hline \multirow{3}{*}{$\begin{array}{l}\text { Mean (St.Dev.) Dependent Var. } \\
\text { N. Mergers Law } 1845\end{array}$} & \multicolumn{5}{|c|}{$0.71(0.71)$} & \multirow{3}{*}{$\begin{array}{l}0.16^{* * *} \\
(0.034)\end{array}$} & \multirow{3}{*}{$\begin{array}{l}0.16^{* * *} \\
(0.037)\end{array}$} \\
\hline & $0.16^{* * *}$ & $0.16^{* * *}$ & $0.16^{* * *}$ & $0.16^{* * *}$ & $0.16^{* * *}$ & & \\
\hline & $(0.031)$ & $(0.031)$ & $(0.031)$ & $(0.034)$ & $(0.034)$ & & \\
\hline F-statistic & 27.5 & 27.2 & 27.5 & 23.7 & 23.6 & 23.1 & 19.2 \\
\hline \multicolumn{8}{|c|}{ Panel B: Second-Stage Results } \\
\hline Mean (St.Dev.) Dependent Var. & \multicolumn{5}{|c|}{$20,016.5(3,846)$} & & \\
\hline Civic rights assoc pc (97-15) & $\begin{array}{c}1,365.8^{* *} \\
(684.1)\end{array}$ & $\begin{array}{c}1,407^{* * *} \\
(519.6)\end{array}$ & $\begin{array}{c}1,445.3^{* * *} \\
(532.7)\end{array}$ & $\begin{array}{c}1,480.1^{* * *} \\
(537.9)\end{array}$ & $\begin{array}{c}1,448.8^{* * *} \\
(524.3)\end{array}$ & $\begin{array}{l}1,462^{* * *} \\
(540.6)\end{array}$ & $\begin{array}{l}1,363^{* *} \\
(559.7)\end{array}$ \\
\hline Human Capital & & Yes & Yes & Yes & Yes & Yes & Yes \\
\hline Innovation & & & Yes & Yes & Yes & Yes & Yes \\
\hline Roads \& Public Infrastructure & & & & Yes & Yes & Yes & Yes \\
\hline Financial Capital & & & & & Yes & Yes & Yes \\
\hline Police Forces & & & & & & Yes & Yes \\
\hline Tourism & & & & & & & Yes \\
\hline Observations & 434 & 434 & 434 & 434 & 434 & 434 & 434 \\
\hline Centered- $R^{2}$ & 0.29 & 0.47 & 0.47 & 0.47 & 0.48 & 0.48 & 0.49 \\
\hline
\end{tabular}

All models include a second-order polynomial function of the population measured in 2015 and 1845, municipal land area, elevation, ruggedness, distance to the sea, mean rainfall, mean temperature, an indicator variable that takes the value 1 if a municipality has more than 100,000 inhabitants, and province fixed effects. Additional controls include the percentage of citizens with secondary or college education in 2001, patents per 1,000 inhabitants in 2015, road density in 1990, sports facilities per 1,000 inhabitants in 2016, and libraries per 1,000 inhabitants in 2014, bank branches per 1,000 inhabitants in 2002, local police officers per 1,000 inhabitants in 2015, and hotels per 1,000 inhabitants in 2015. Clustered standard errors at the district level in parentheses. ${ }^{*} p<0.10$, ${ }^{* *} p<0.05,{ }^{* * *} p<0.01$. 
Table 10: IV Results with Civic Behavior, Social Interaction and Resident Engagemant

\begin{tabular}{lcc}
\hline \hline \multicolumn{3}{c}{ Panel A: First-Stage Results } \\
\hline Mean (St.Dev.) Dep. Var. & $2.4(3.6)$ \\
\hline Number of Old Townships & $1.43^{* * *}$ & $1.24^{* * *}$ \\
& $(0.04)$ & $(0.07)$ \\
\hline F-statistic Panel B: Second-Stage Results \\
\hline \hline \multicolumn{2}{c}{$1,332.6$} & 288.4 \\
\hline Mean (St.Dev.) Dep. Var. & $0.02^{* * *}$ & $0.03^{*}$ \\
\hline Civic Behavior & $(0.006)$ & $(0.017)$ \\
\hline & 0.07 & 0.22 \\
\hline Centered- $R^{2}$ & \multicolumn{2}{c}{$7.6(0.6)$} \\
\hline Mean (St.Dev.) Dep. Var. & $0.05^{* * *}$ \\
\hline Social Interaction & $0.04^{* * *}$ & $(0.017)$ \\
\hline Centered- $R^{2}$ & $(0.010)$ & 0.36 \\
\hline Mean (St.Dev.) Dep. Var. & 0.17 & $4.4(0.7)$ \\
\hline Resident Engagement & $0.01^{* *}$ & 0.02 \\
& $(0.006)$ & $(0.02)$ \\
\hline Centered- $R^{2}$ & 0.01 & 0.13 \\
\hline Observations & 98 & 98 \\
Additional controls & No & Yes \\
\hline \hline
\end{tabular}

All models include population of the municipality measured in 2012 and 1845. Additional controls include include municipal land area, elevation, ruggedness, distance to the sea, mean and standard deviation of rainfall, mean and standard deviation of temperatures, and a dummy variable that takes the value 1 if a municipality has more than 100,000 inhabitants. Robust standard errors in parentheses. ${ }^{*} p<0.10,{ }^{* *} p<0.05,{ }^{* * *} p<0.01$. 
Figure 1: Changes in the Municipal Map of Catalonia (1800-2015)

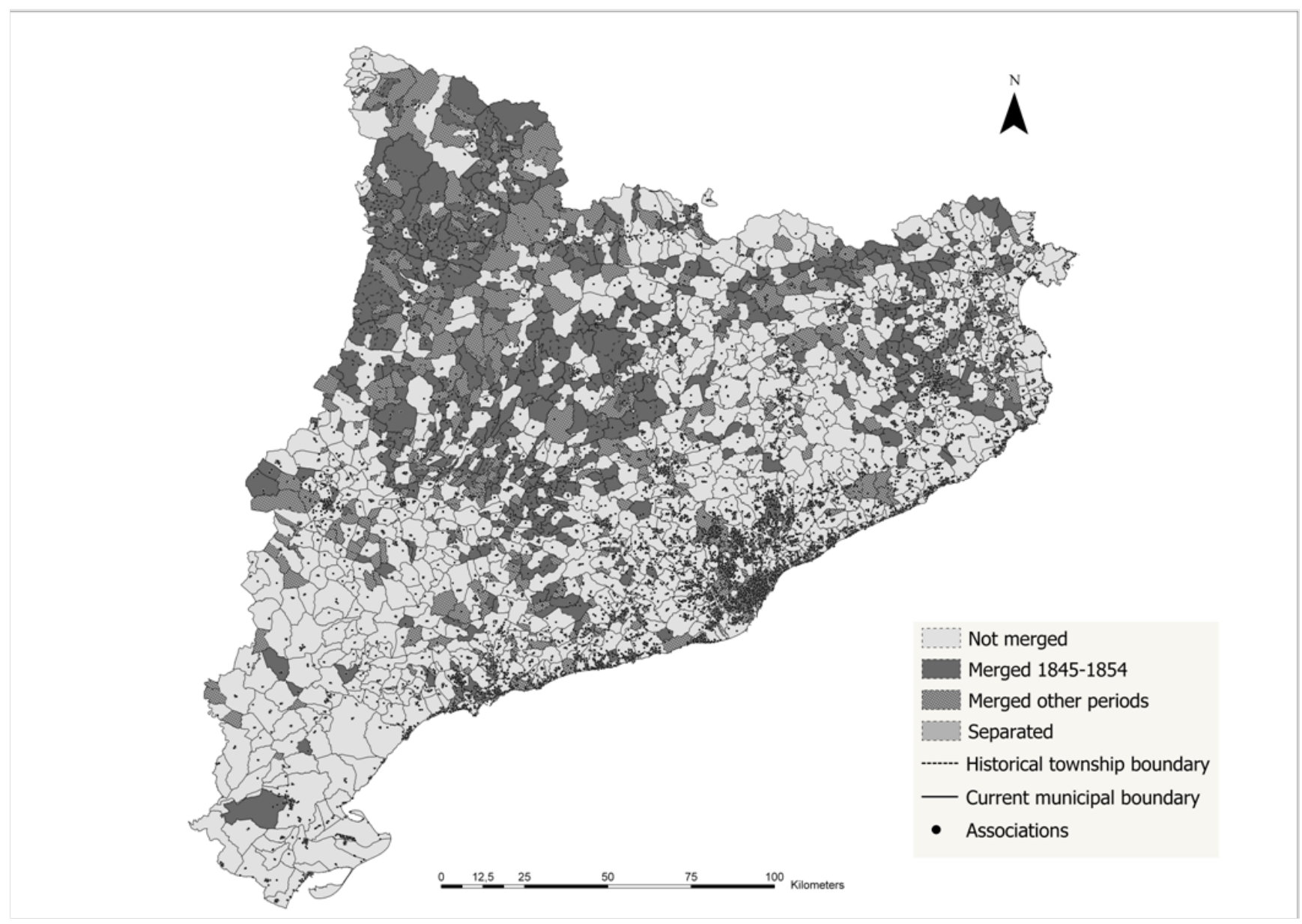

Own elaboration based on Burgueño and Lasso de la Vega (2002). The dots show all types of associations registered during period $1942-2015$. 
Figure 2: Mergers and Civic Rights Associations 1997-2015 (Zoomed-in View)

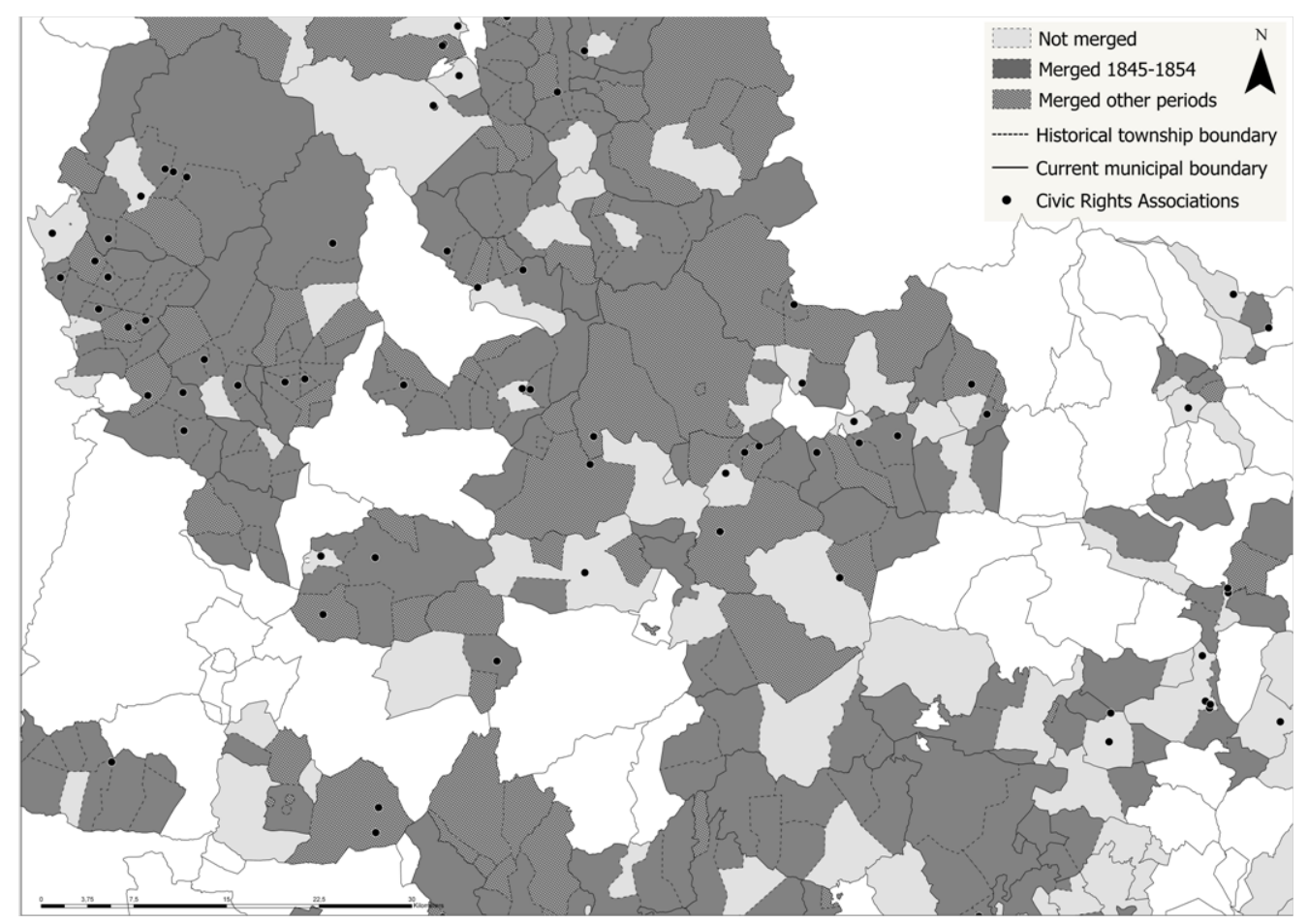

Own elaboration from historical maps. In light grey we show old townships that became the main town or village of modern municipalities. In dark grey we show small townships merged with others during the period 1845-1854. The black lines delimit the borders of current municipalities, and the hatched ones the borders of the old townships. The dots depict the presence of a civic rights association registered during the period 1997-2015. Municipalities left blank are not included in our RD sample (i.e., their main town or village had more than 60 householders in 1845 , they did not experience any merge during during the implementation period of the 1845 Act, or they were newly established as a result of some division process). 
Figure 3: RD Results

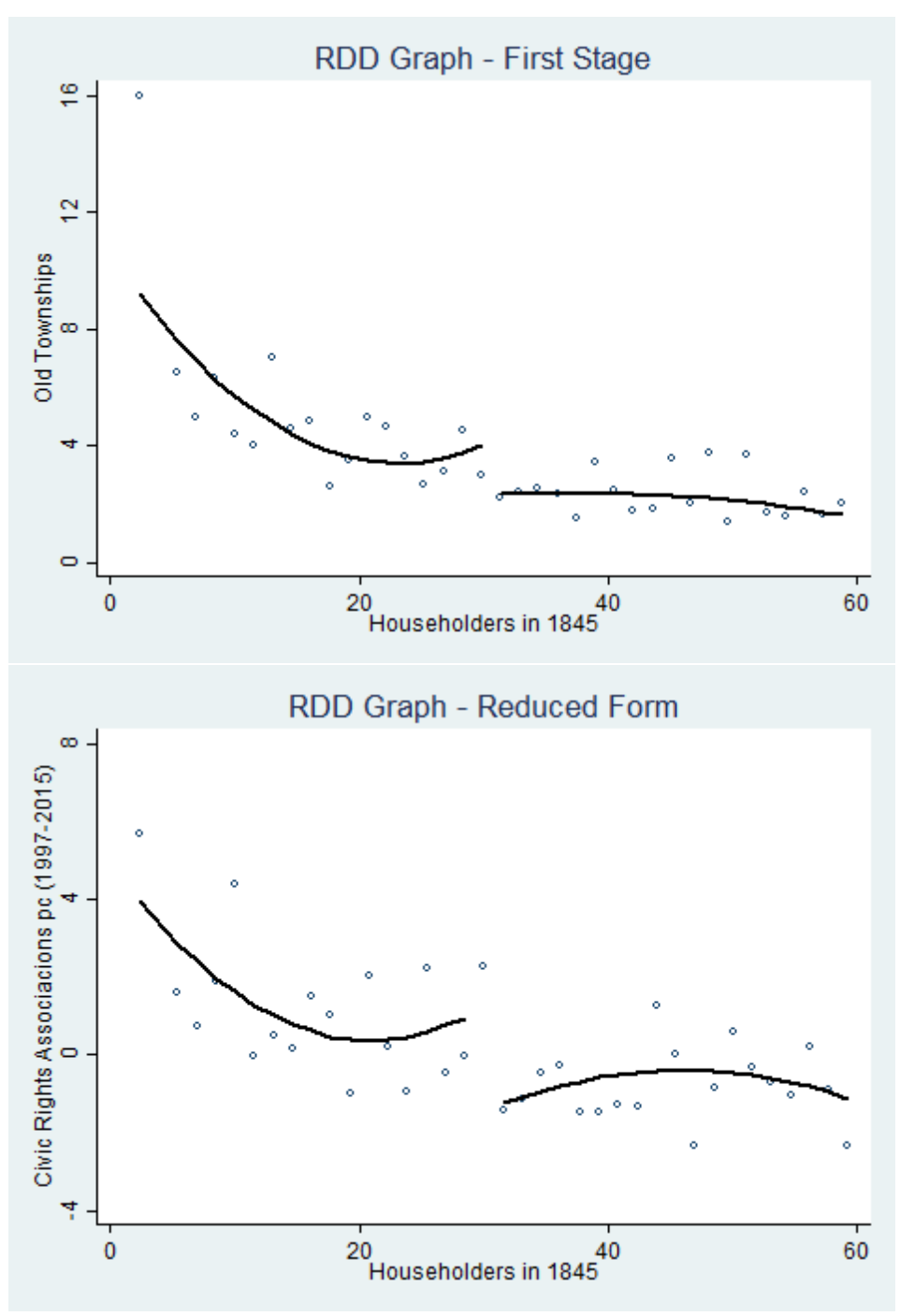

In the upper panel, the dots are the average number of old townships in 1800. In the lower one, the dots are the averaged residuals of a regression of the number of voluntary associations that promote civic rights in the period 1997-2015 on population in 2015 (second order polynomial and winsorized at the $5 \%$ level). The lines are regression fits from a model of the number of old townships in 1800 in the upper panel, and the number of voluntary associations in 1997-2015 in the lower one, on population in 1845 and its squared, a dummy variable that takes the value 1 if population is higher than the threshold ( 30 householders) and the interaction terms of population in 1845 (and its square) with the dummy variable. 
Figure 4: Placebo RD Results. Smoothness of Other Variables: Population Size 1845, Area and Literacy Rates in 1860 and 1900
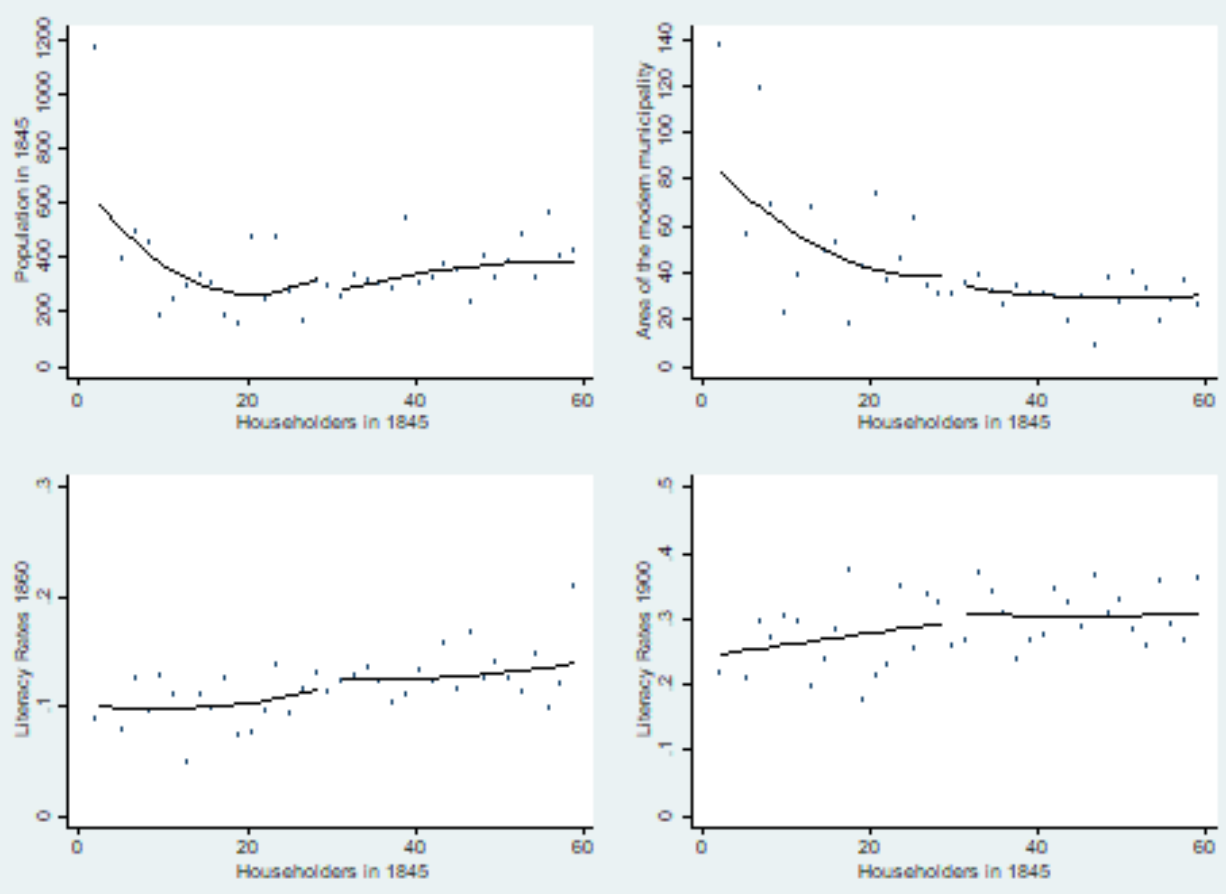

The dots are the average number of old townships in 1800. The lines are regression fits from a model of the number of old townships in 1800 on population in 1845 and its square, a dummy variable that takes the value 1 if population is higher than the threshold (30 householders) and the interaction terms of population in 1845 (and its squared) with the dummy variable.

Figure 5: McCrary Density Test of Manipulation of the Running Variable
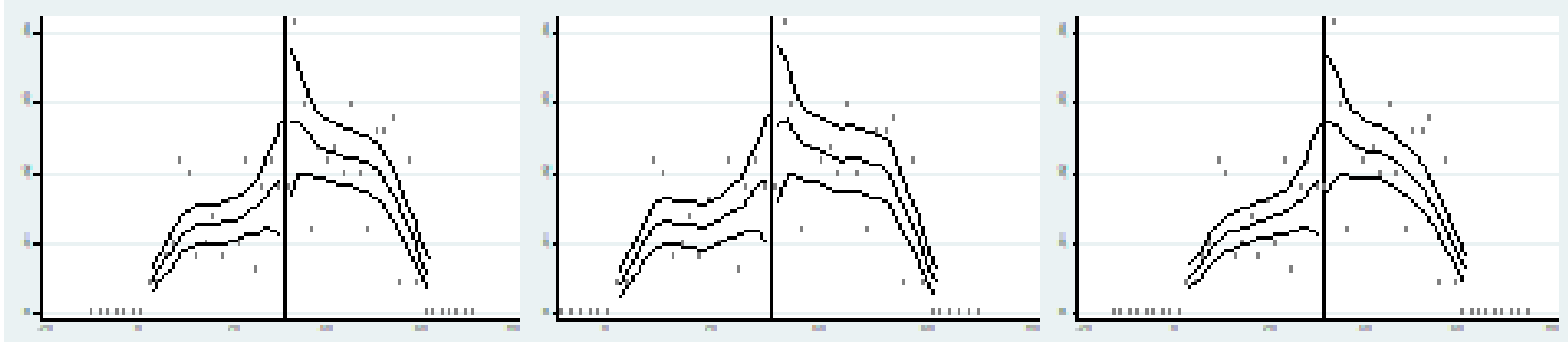

Own elaboration using the Stata command DCdensity. The first panel uses the default bandwidth provided by the program (11.4), the second one is set by the authors at 9 and the third one at 14 . 
Figure 6: RD Results with Smaller Bandwidth

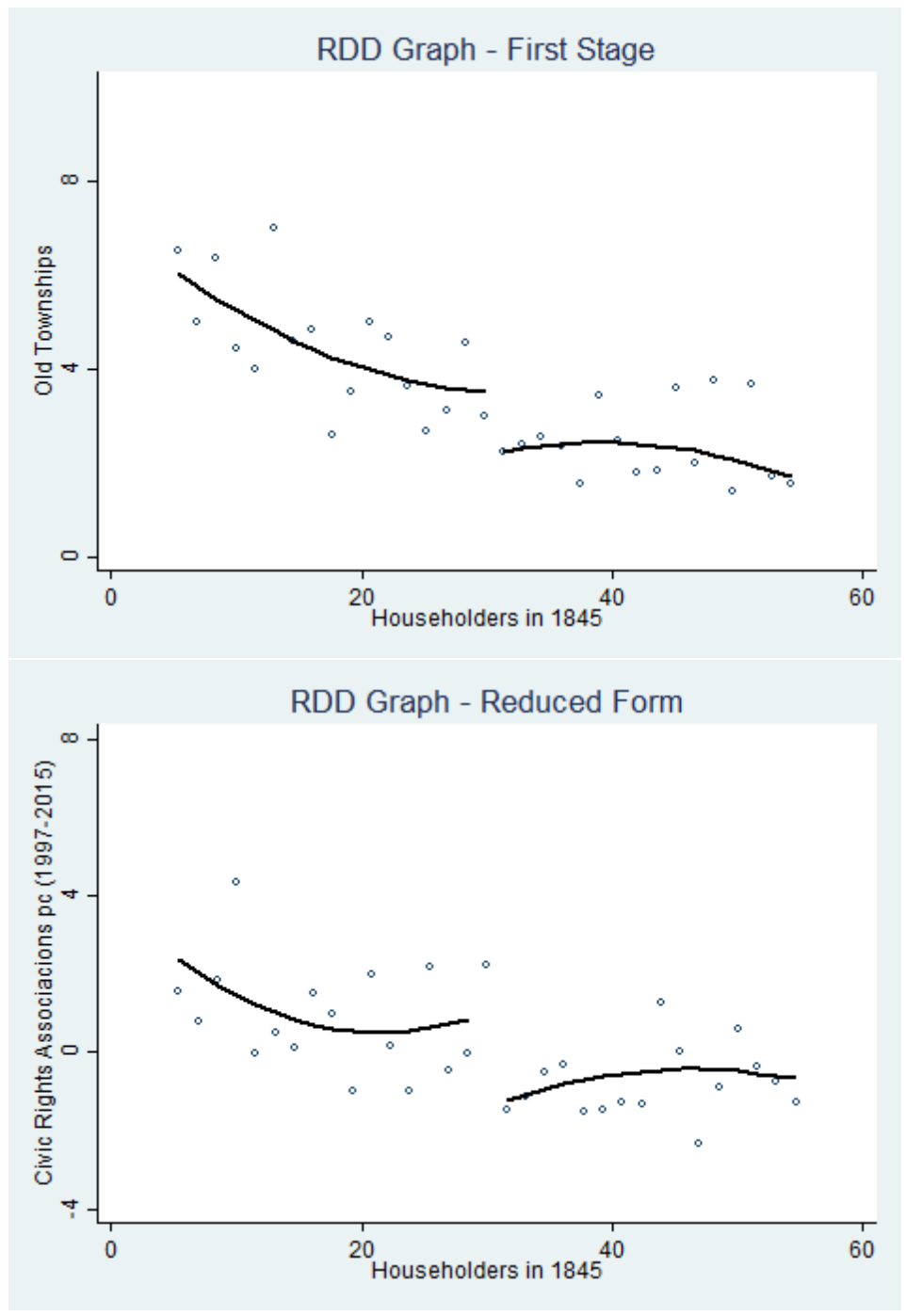

In the upper panel, the dots are the average number of old townships in 1800. In the lower one, the dots are the averaged residuals of a regression of the number of voluntary associations that promote civic rights in the period 1997-2015 on population in 2015 (second order polynomial and winsorized at the $5 \%$ level). The lines are regression fits from a model of the number of old townships in 1800 in the upper panel, and the number of voluntary associations in 1997-2015 in the lower one, on population in 1845 and its squared, a dummy variable that takes the value 1 if population is higher than the threshold ( 30 householders) and the interaction terms of population in 1845 (and its square) with the dummy variable. 


\section{Figure 7: Placebo RD Results with Threshold at 100 Inhabitants}

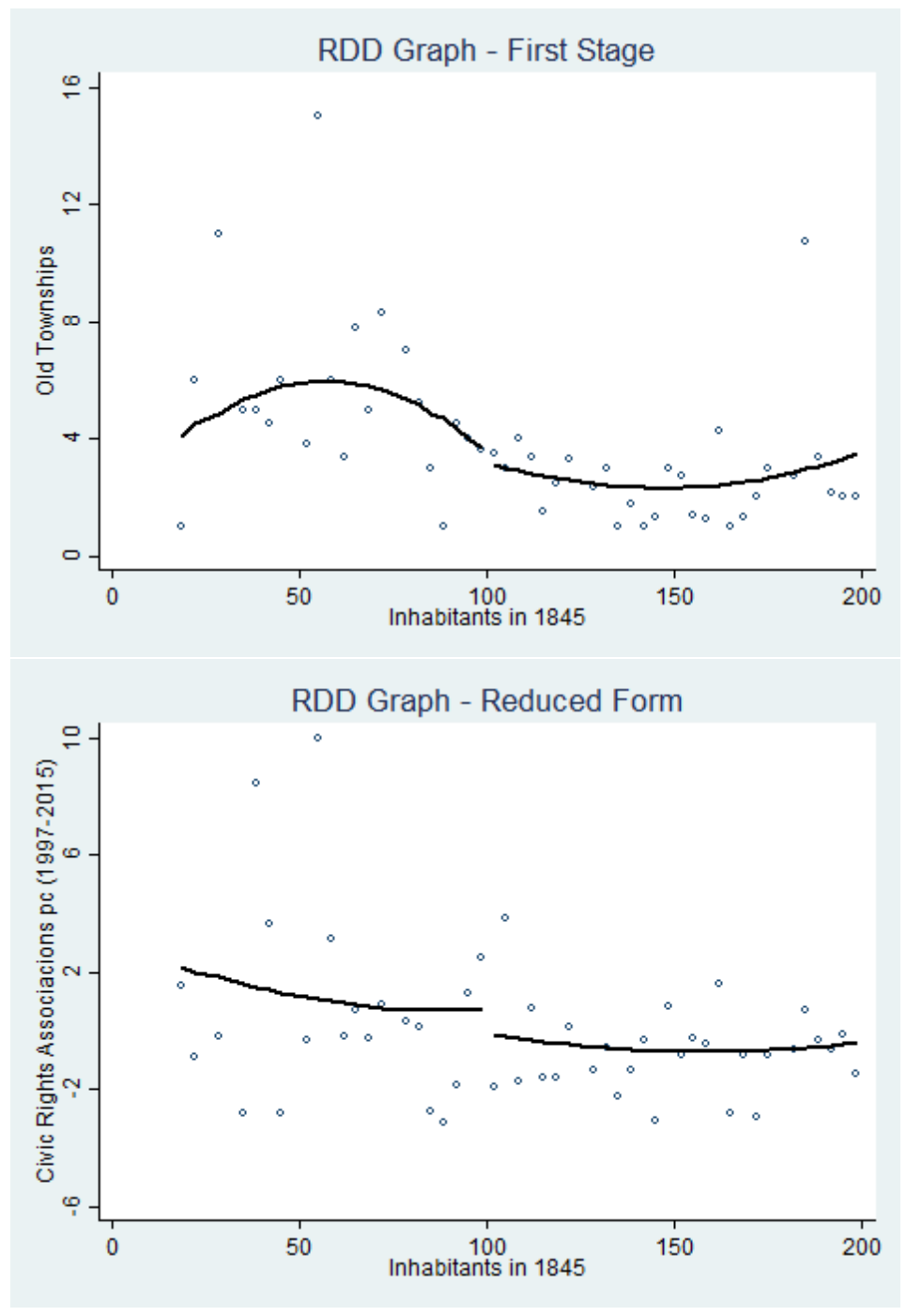

In the upper panel, the dots are the average number of old townships in 1800. In the lower one, the dots are the averaged residuals of a regression of the number of voluntary associations that promote civic rights in the period 1997-2015 on population in 2015 (second order polynomial and winsorized at the 5\% level). The lines are regression fits from a model of the number of old townships in 1800 in the upper panel, and the number of voluntary associations in 1997-2015 in the lower one, on population in 1845 and its squared, a dummy variable that takes the value 1 if population is higher than the threshold (100 inhabitants) and the interaction terms of population in 1845 (and its square) with the dummy variable. 


\section{Appendix: Additional Tables}

Table 11: Effect of Number of Old Townships on Exemptions from Disentailment

\begin{tabular}{lcc|cc}
\hline \hline & \multicolumn{2}{c}{ Probit Model } & \multicolumn{2}{c}{ Poisson Model } \\
\hline & $(1)$ & $(2)$ & $(3)$ & $(4)$ \\
Mean (St.Dev.) Dep. Var. & 0.12 & $(0.32)$ & 0.05 & $(0.16)$ \\
\hline Number of Old Townships & $0.016^{* * *}$ & $0.004^{* * *}$ & $0.048^{* * *}$ & $0.036^{* *}$ \\
& $(0.003)$ & $(0.001)$ & $(0.016)$ & $(0.014)$ \\
\hline Province FE & Yes & Yes & Yes & Yes \\
Additional controls & No & Yes & No & Yes \\
\hline Observations & 919 & 919 & 919 & 919 \\
Pseudo- $R^{2}$ & 0.15 & 0.60 & 0.13 & 0.43 \\
\hline \hline
\end{tabular}

The dependent variable measures the proportion of the municipal area which was exempted from disentailment, according to the 1901 catalog; it is expressed as a binary variable in columns (1) and (2). The coefficients of the probit model show the marginal effects. Additional controls include population density in 1900, elevation and ruggedness. Robust standard errors in parentheses. ${ }^{*} p<0.10,{ }^{* *} p<0.05,{ }^{* * *}$ $p<0.01$. 


\section{Figure 8: RD Results with Blood Donations}
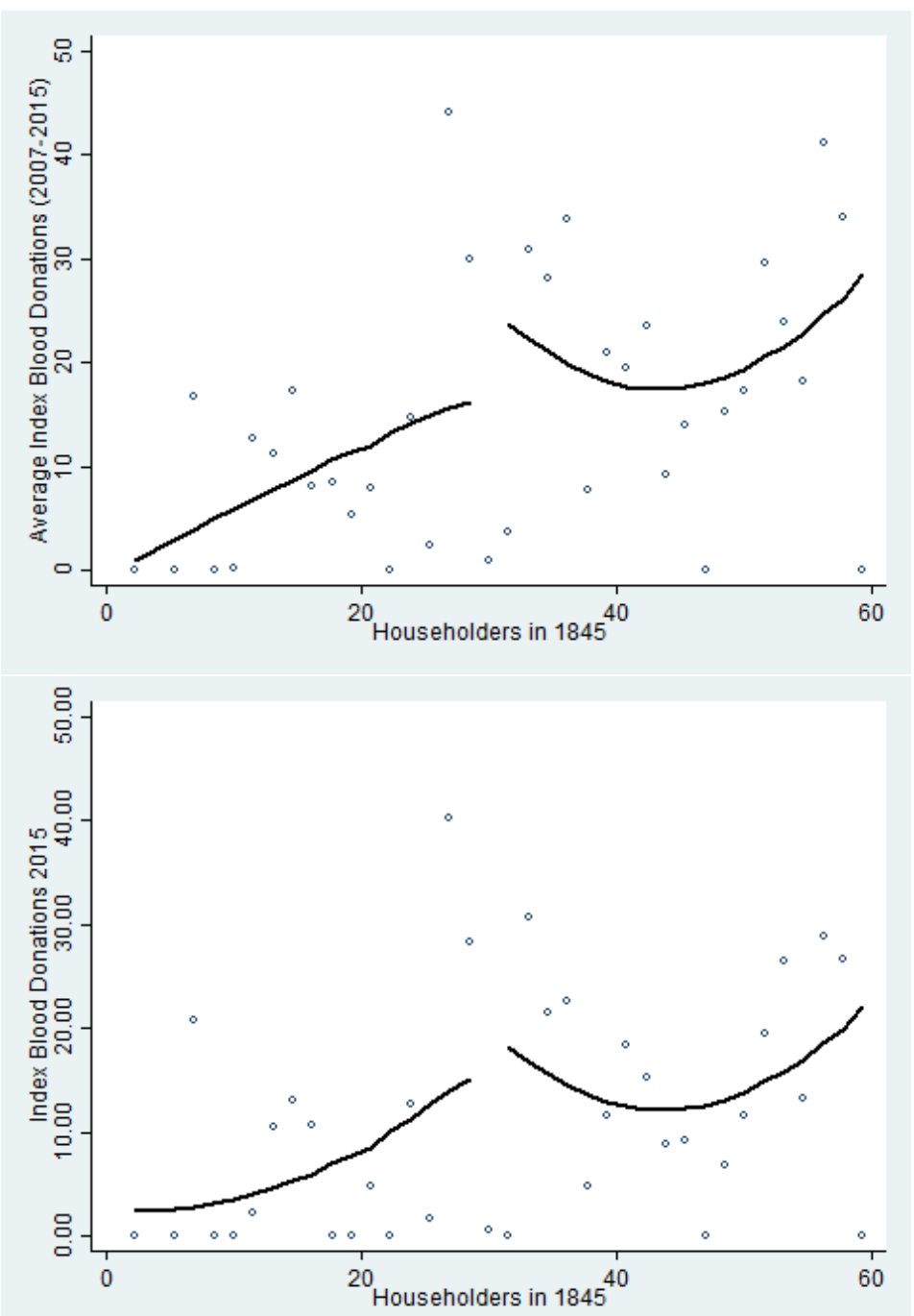

The dots are the average number the blood donations index, in the upper panel these are averaged for the period 2007-2015, and the lower panel shows the index only for 2015. The lines are regression fits from a model of the index of blood donations on population in 1845 and its square, a dummy variable that takes the value 1 if population is higher than the threshold ( 30 householders) and the interaction terms of population in 1845 (and its square) with the dummy variable. The coefficients and standard errors (in parentheses) are 8.2 (13.4) and 2.8 (12.5) in the upper and lower panel, respectively. 


\section{Figure 9: RD Results with Transparency Index}
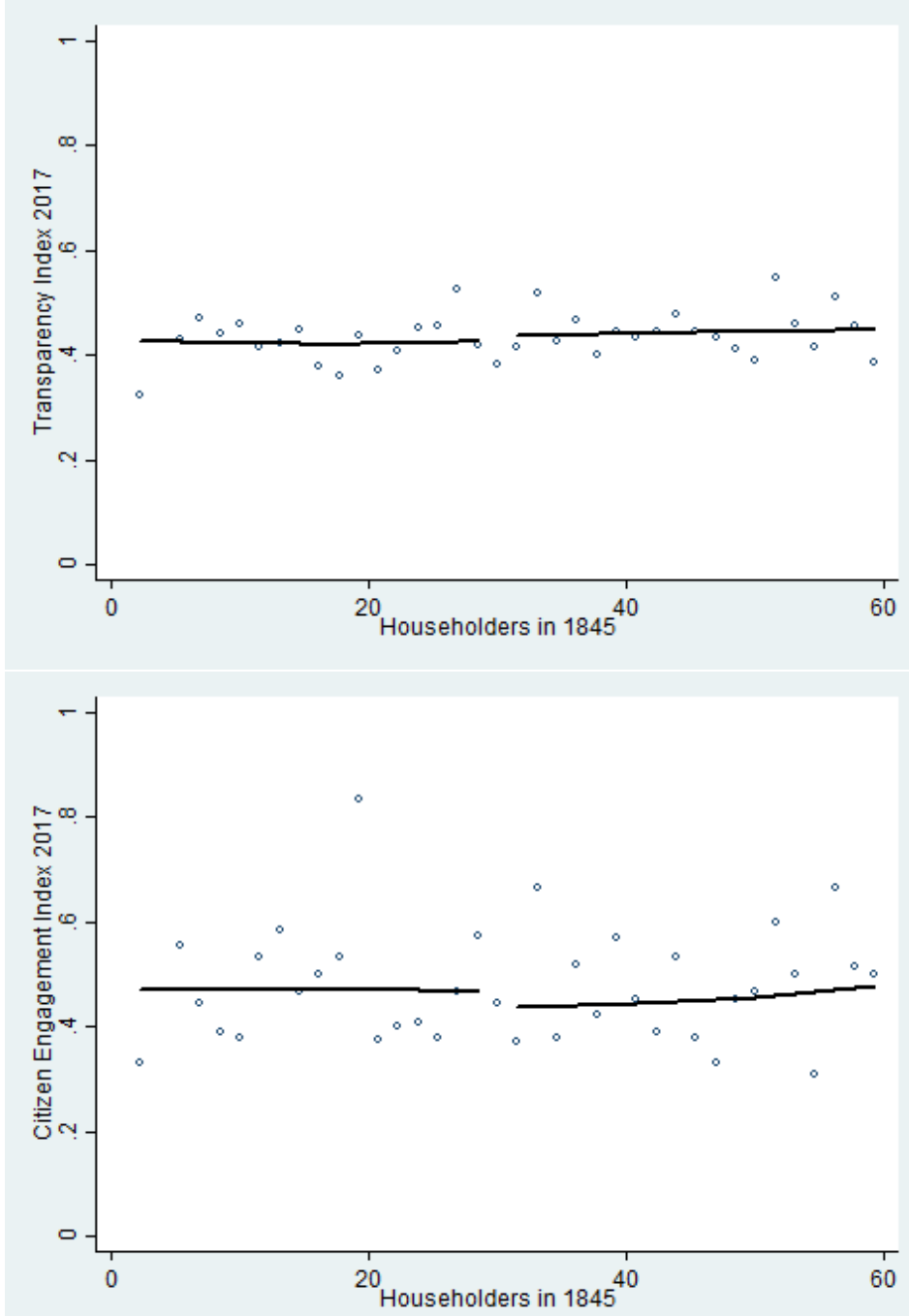

The dots are the average transparency index in the upper panel, and the average citizen participation index in the lower panel, both at the municipal level. These indexes are computed in 2017, based on survey questions, and normalized between 0 (lowest transparency/participation) and 1 (highest transparency/participation). The lines are regression fits from a model of the transparency index on population in 1845 and its square, a dummy variable that takes the value 1 if population is higher than the threshold ( 30 householders) and the interaction terms of population in 1845 (and its square) with the dummy variable. The coefficients and standard errors (in parentheses) are 0.008 (0.037) and -0.028 (0.078) in the upper and lower panel, respectively. 


\section{Table 12: Data Sources}

\begin{tabular}{|c|c|}
\hline Variables & Source \\
\hline Population (contemporary) & $\begin{array}{l}\text { National Institute for Statistics (Instituto Nacional de Es- } \\
\text { tadística, INE) }\end{array}$ \\
\hline Population in 1845 & $\begin{array}{l}\text { Diccionario Geográfico-Estadístico-Histórico de España y sus } \\
\text { posesiones de Ultramar, by Pascual Madoz, Madrid 1845- } \\
1850 .\end{array}$ \\
\hline Population and literacy rates in 1860 & $\begin{array}{l}\text { Censo de la población de España según el recuento verificado } \\
\text { en } 25 \text { de diciembre de 1860, Junta General de Estadística, } \\
\text { Madrid } 1863 \text { ( } 1860 \text { census) }\end{array}$ \\
\hline Literacy rates in 1900 & $\begin{array}{l}\text { Censo de la población de España según el empadronamiento } \\
\text { hecho en la Peninsula é Islas Adyacentes el } 31 \text { de diciembre } \\
\text { de 1900, Dirección General del Instituto Geográfico y Es- } \\
\text { tadístico, Madrid, } 1902\end{array}$ \\
\hline Voluntary associations & $\begin{array}{l}\text { Generalitat de Catalunya. Departament de Justícia. Direcció } \\
\text { General de Dret i d'Entitats Jurídiques. Servei de Coordinació } \\
\text { Tècnica i Assessorament d'Entitats de Dret Públic }\end{array}$ \\
\hline Climatic and geographic variables & Institut Cartogràfic i Geològic de Catalunya \\
\hline Income tax base per capita & $\begin{array}{l}\text { Catalan Institute of Statistics (Institut d'Estadística de } \\
\text { Catalunya, IDESCAT) }\end{array}$ \\
\hline Human Capital & IDESCAT, Cens de Població 2001 \\
\hline Patents & $\begin{array}{l}\text { Spanish Office of Patents and Trademarks, Ministry of } \\
\text { Industry, Trade and Tourism }\end{array}$ \\
\hline Road density & $\begin{array}{l}\text { Based on Font i Garolera, Jaume (1993), "La formació } \\
\text { històrica de la xarxa de carreteres a Catalunya", Estudi } \\
\text { General 13: 127-152 }\end{array}$ \\
\hline Sports facilities & IDESCAT, based on Consell Català de l'Esport \\
\hline Libraries & IDESCAT, Estadística de biblioteques \\
\hline Bank branches & $\begin{array}{l}\text { IDESCAT, based on the Economic Activities Tax Impost } \\
\text { d'activitats econòmiques (IAE) }\end{array}$ \\
\hline Local police officers & $\begin{array}{l}\text { IDESCAT, based on data from the Catalan Ministry of } \\
\text { Home Affairs }\end{array}$ \\
\hline Hotels & $\begin{array}{l}\text { IDESCAT, based on data from Direcció General de Turisme, } \\
\text { Catalan Department of Business and Occupation }\end{array}$ \\
\hline $\begin{array}{l}\text { Civic Behavior, Social Interaction, and Resident } \\
\text { Engagement }\end{array}$ & $\begin{array}{l}\text { Public Safety Survey for Catalonia (Enquesta de seguretat } \\
\text { pública de Catalunya). Catalan Ministry of Home Affairs. } \\
2012\end{array}$ \\
\hline Blood donations & Banc de Sang $i$ Teixits. Catalan Health Department \\
\hline Transparency and Citizen Participation & Fundació Pi i Sunyer \\
\hline
\end{tabular}


Table 13: IV Results with Restricted Sample. Long-lasting Effects on Voluntary Associations 1979-1996

\begin{tabular}{|c|c|c|c|}
\hline \multicolumn{4}{|c|}{ Panel A: First-Stage Results } \\
\hline \multirow{2}{*}{$\begin{array}{l}\text { Mean (St.Dev.) Dep. Var. } \\
\text { N. Mergers Law } 1845\end{array}$} & \multicolumn{3}{|c|}{$3.1(3.3)$} \\
\hline & $0.94^{* * *}$ & $0.93^{* * *}$ & $0.93^{* * *}$ \\
\hline & $(0.052)$ & $(0.053)$ & $(0.055)$ \\
\hline F-statistic & 331.3 & 311.9 & 282.3 \\
\hline \multicolumn{4}{|c|}{ Panel B: Second-Stage Results } \\
\hline Mean (St.Dev.) Dep. Var. & \multicolumn{3}{|c|}{$8.6(8.0)$} \\
\hline \multirow[t]{2}{*}{ Number of Old Townships } & 0.14 & 0.22 & 0.14 \\
\hline & $(0.185)$ & $(0.194)$ & $(0.192)$ \\
\hline Observations & 292 & 292 & 292 \\
\hline Centered- $R^{2}$ & 0.13 & 0.21 & 0.23 \\
\hline Province FE & Yes & Yes & Yes \\
\hline Geographic \& climatic controls & No & Yes & Yes \\
\hline Additional population controls & No & No & Yes \\
\hline
\end{tabular}

All models include population size measured in 1996 and 1845, and municipal land area. Geographic and climatic controls include elevation, ruggedness, distance to the sea and to a river, mean and standard deviation of rainfall, and mean and standard deviation of temperatures. Additional population controls include population squared both in 1845 and in 1996. Robust standard errors in parentheses. ${ }^{*} p<0.10,{ }^{* *} p<0.05,{ }^{* * *} p<0.01$. 
Table 14: IV Results by Types of Associations, with Restricted Sample, 1997-2015. Second-Stage Results

\begin{tabular}{|c|c|c|c|}
\hline \multicolumn{4}{|c|}{ Panel A: Social Care and Health Associations } \\
\hline \multirow{3}{*}{$\begin{array}{l}\text { Mean (St.Dev.) Dep. Var. } \\
\text { Number of Old Townships }\end{array}$} & \multicolumn{3}{|c|}{$0.3(1.2)$} \\
\hline & -0.00 & 0.00 & 0.00 \\
\hline & $(0.022)$ & $(0.021)$ & $(0.021)$ \\
\hline Centered- $R^{2}$ & 0.03 & 0.05 & 0.05 \\
\hline \multicolumn{4}{|c|}{ Panel B: Scientific Knowledge and Learning Associations } \\
\hline Mean (St.Dev.) Dep. Var. & \multicolumn{3}{|c|}{$0.5(1.2)$} \\
\hline \multirow[t]{2}{*}{ Number of Old Townships } & 0.00 & -0.01 & -0.01 \\
\hline & $(0.032)$ & $(0.035)$ & $(0.033)$ \\
\hline Centered- $R^{2}$ & 0.02 & 0.04 & 0.04 \\
\hline \multicolumn{4}{|c|}{ Panel C: Lobbying Associations } \\
\hline Mean (St.Dev.) Dep. Var. & \multicolumn{3}{|c|}{$1.4(3.4)$} \\
\hline \multirow[t]{2}{*}{ Number of Old Townships } & 0.15 & 0.12 & 0.13 \\
\hline & $(0.093)$ & $(0.092)$ & $(0.097)$ \\
\hline Centered- $R^{2}$ & 0.04 & 0.06 & 0.06 \\
\hline \multicolumn{4}{|c|}{ Panel D: Environment Protection Associations } \\
\hline Mean (St.Dev.) Dep. Var. & \multicolumn{3}{|c|}{$1.6(3.5)$} \\
\hline \multirow[t]{2}{*}{ Number of Old Townships } & 0.16 & 0.13 & 0.10 \\
\hline & $(0.095)$ & $(0.079)$ & $(0.079)$ \\
\hline Centered- $R^{2}$ & 0.04 & 0.15 & 0.16 \\
\hline Observations & 292 & 292 & 292 \\
\hline Province FE & Yes & Yes & Yes \\
\hline Geographic \& climatic controls & No & Yes & Yes \\
\hline Additional population controls & No & No & Yes \\
\hline \multicolumn{4}{|c|}{$\begin{array}{l}\text { All models include population size measured in } 2015 \text { and } 1845 \text {, and municipal } \\
\text { land area. Geographic and climatic controls include elevation, ruggedness, } \\
\text { distance to the sea and to a river, mean and standard deviation of rainfall, and } \\
\text { mean and standard deviation of temperatures. Additional population controls } \\
\text { include population squared both in } 1845 \text { and in } 2015 \text {. Robust standard errors } \\
\text { in parentheses. }{ }^{*} p<0.10,{ }^{* *} p<0.05,{ }^{* * *} p<0.01 \text {. }\end{array}$} \\
\hline
\end{tabular}


Table 15: Reduced-Form Results. Income Tax Base per Capita 2015

\begin{tabular}{lcccccccc}
\hline \hline Mean (St.Dev.) Dependent Var. & \multicolumn{7}{c}{$20,016.5(3,846)$} \\
\hline N. Mergers Law 1845 & $219.7^{* *}$ & $226.4^{* * *}$ & $233^{* * *}$ & $242.3^{* * *}$ & $236.4^{* * *}$ & $238.3^{* * *}$ & $222.3^{* * *}$ \\
& $(88.1)$ & $(64.7)$ & $(65.1)$ & $(63.3)$ & $(61.3)$ & $(62.4)$ & $(63.8)$ \\
\hline Human Capital & & Yes & Yes & Yes & Yes & Yes & Yes \\
Innovation & & & Yes & Yes & Yes & Yes & Yes \\
Roads \& Public Infrastructure & & & & Yes & Yes & Yes & Yes \\
Financial Capital & & & & Yes & Yes & Yes \\
Police Forces & & & & & & Yes & Yes \\
Tourism & 434 & 434 & 434 & 434 & 434 & 434 & 434 \\
\hline Observations & & & & & & & Yes \\
Centered- $R^{2}$ & 0.33 & 0.52 & 0.53 & 0.53 & 0.53 & 0.53 & 0.54 \\
\hline \hline
\end{tabular}

All models include a second-order polynomial function of the population measured in 2015 and 1845, municipal land area, elevation, ruggedness, distance to the sea, mean rainfall, mean temperature, an indicator variable that takes the value 1 if a municipality has more than 100,000 inhabitants, and province fixed effects. Additional controls include the percentage of citizens with secondary or college education in 2001, patents per 1,000 inhabitants in 2015, road density in 1990, sports facilities per 1,000 inhabitants in 2016, and libraries per 1,000 inhabitants in 2014, bank branches per 1,000 inhabitants in 2002, local police officers per 1,000 inhabitants in 2015, and hotels per 1,000 inhabitants in 2015. Clustered standard errors at the district level in parentheses. ${ }^{*} p<0.10,{ }^{* *} p<0.05,{ }^{* * *} p<0.01$. 
Table 16: IV Results. Income Tax Base per Capita 2005 with Civic Rights Associations (19972005)

\begin{tabular}{|c|c|c|c|c|c|c|c|}
\hline \multicolumn{8}{|c|}{ Year 2005} \\
\hline \multicolumn{8}{|c|}{ Panel A: First-Stage Results } \\
\hline Mean (St.Dev.) Dependent Var. & & & 0.37 & $(0.52)$ & & & \\
\hline \multirow[t]{2}{*}{ N. Mergers Law 1845} & $0.13^{* * *}$ & $0.13^{* * *}$ & $0.13^{* * *}$ & $0.13^{* * *}$ & $0.13^{* * *}$ & $0.13^{* * *}$ & $0.13^{* * *}$ \\
\hline & $(0.030)$ & $(0.030)$ & $(0.030)$ & $(0.030)$ & $(0.030)$ & $(0.031)$ & $(0.033)$ \\
\hline F-statistic & 18 & 18.1 & 18 & 17 & 17.1 & 16.9 & 14.8 \\
\hline \multicolumn{8}{|c|}{ Panel B: Second-Stage Results } \\
\hline Mean (St.Dev.) Dependent Var. & \multicolumn{6}{|c|}{$15,693.4(4,146.6)$} & \\
\hline Civic rights assoc pc (97-05) & $\begin{array}{c}1,966.7^{* *} \\
(900.4) \\
\end{array}$ & $\begin{array}{c}1,964.5^{* * *} \\
(604.5) \\
\end{array}$ & $\begin{array}{c}2,035.4^{* * *} \\
(610.4) \\
\end{array}$ & $\begin{array}{c}2,332.2^{* * *} \\
(686.4) \\
\end{array}$ & $\begin{array}{c}2,288.6^{* * *} \\
(673.5) \\
\end{array}$ & $\begin{array}{c}2,219.9^{* * *} \\
(665.5) \\
\end{array}$ & $\begin{array}{c}2,035.4^{* * *} \\
(686.7) \\
\end{array}$ \\
\hline Observations & 416 & 416 & 416 & 416 & 416 & 416 & 416 \\
\hline Centered- $R^{2}$ & 0.29 & 0.49 & 0.49 & 0.48 & 0.49 & 0.50 & 0.51 \\
\hline Human Capital & & Yes & Yes & Yes & Yes & Yes & Yes \\
\hline Innovation & & & Yes & Yes & Yes & Yes & Yes \\
\hline Roads \& Public Infrastructure & & & & Yes & Yes & Yes & Yes \\
\hline Financial Capital & & & & & Yes & Yes & Yes \\
\hline Police Forces & & & & & & Yes & Yes \\
\hline Tourism & & & & & & & Yes \\
\hline
\end{tabular}

All models include a second-order polynomial function of the population measured in 2005 and 1845, municipal land area, elevation, ruggedness, distance to the sea, mean rainfall, mean temperature, an indicator variable that takes the value 1 if a municipality has more than 100,000 inhabitants, and province fixed effects. Additional controls include the percentage of citizens with secondary or college education in 2001, patents per 1,000 inhabitants in 2008, road density in 1990, sports facilities per 1,000 inhabitants in 2001, and libraries per 1,000 inhabitants in 2004, bank branches per 1,000 inhabitants in 2002, local police officers per 1,000 inhabitants in 2005, and hotels per 1,000 inhabitants in 2005. Clustered standard errors at the district level in parentheses. ${ }^{*} p<0.10,{ }^{* *} p<0.05,{ }^{* * *} p<0.01$. 
Table 17: IV Results. Income Tax Base per Capita 2010 with Civic Rights Associations (19972010)

\begin{tabular}{|c|c|c|c|c|c|c|c|}
\hline \multicolumn{8}{|c|}{ Year 2010} \\
\hline \multicolumn{8}{|c|}{ Panel A: First-Stage Results } \\
\hline Mean (St.Dev.) Dependent Var. & \multicolumn{6}{|c|}{$0.55(0.61)$} & \\
\hline \multirow[t]{2}{*}{ N. Mergers Law 1845} & $0.14^{* * *}$ & $0.14^{* * *}$ & $0.14^{* * *}$ & $0.15^{* * *}$ & $0.15^{* * *}$ & $0.15^{* * *}$ & $0.15^{* * *}$ \\
\hline & $(0.028)$ & $(0.028)$ & $(0.028)$ & $(0.031)$ & $(0.031)$ & $(0.031)$ & $(0.036)$ \\
\hline F-statistic & 25.9 & 25.2 & 26.9 & 22.9 & 23 & 22.6 & 17.7 \\
\hline \multicolumn{8}{|c|}{ Panel B: Second-Stage Results } \\
\hline \multicolumn{3}{|l|}{ Mean (St.Dev.) Dependent Var. } & \multicolumn{2}{|c|}{$19,391.9(3,843)$} & & & \\
\hline \multirow[t]{2}{*}{ Civic rights assoc pc (97-10) } & $1,547.1^{* *}$ & $1,692.4^{* * *}$ & $1,714.3^{* * *}$ & $1,826.7^{* * *}$ & $1,815.9^{* * *}$ & $1,834^{* * *}$ & $1,671.4^{* * *}$ \\
\hline & $(683)$ & $(500.1)$ & $(510)$ & $(525.4)$ & $(520.5)$ & $(545.5)$ & $(550.1)$ \\
\hline Observations & 435 & 435 & 435 & 435 & 435 & 435 & 435 \\
\hline Centered- $R^{2}$ & 0.26 & 0.45 & 0.45 & 0.45 & 0.45 & 0.46 & 0.48 \\
\hline Human Capital & & Yes & Yes & Yes & Yes & Yes & Yes \\
\hline Innovation & & & Yes & Yes & Yes & Yes & Yes \\
\hline Roads \& Public Infrastructure & & & & Yes & Yes & Yes & Yes \\
\hline Financial Capital & & & & & Yes & Yes & Yes \\
\hline Police Forces & & & & & & Yes & Yes \\
\hline Tourism & & & & & & & Yes \\
\hline
\end{tabular}

All models include a second-order polynomial function of the population measured in 2010 and 1845, municipal land area, elevation, ruggedness, distance to the sea, mean rainfall, mean temperature, an indicator variable that takes the value 1 if a municipality has more than 100,000 inhabitants, and province fixed effects. Additional controls include the percentage of citizens with secondary or college education in 2001, patents per 1,000 inhabitants in 2010, road density in 1990, sports facilities per 1,000 inhabitants in 2010, and libraries per 1,000 inhabitants in 2010, bank branches per 1,000 inhabitants in 2002, local police officers per 1,000 inhabitants in 2010, and hotels per 1,000 inhabitants in 2010. Clustered standard errors at the district level in parentheses. ${ }^{*} p<0.10,{ }^{* *} p<0.05,{ }^{* * *} p<0.01$. 


\section{Table 18: Correlation between Associations, Civic Behavior, Social Interaction and Resident}

\section{Engagement}

\begin{tabular}{|l|c|c|c|}
\hline \hline & Civic Behavior & Social Interaction & Resident Engagement \\
\hline & $(1)$ & $(2)$ & $(3)$ \\
\hline Mean (St.Dev.) Dep. Var. & $6.09(0.51)$ & $7.57(0.64)$ & $4.39(0.71)$ \\
\hline Total Associations pc 1997-2012 & $1.34^{* * *}$ & $1.67^{* * *}$ & $0.97^{* * *}$ \\
& $(0.046)$ & $(0.054)$ & $(0.035)$ \\
\hline$R^{2}$ & 0.91 & 0.91 & 0.89 \\
\hline Civic Rights Associations pc 1997-2012 & $9.84^{* * *}$ & $12.37^{* * *}$ & $7.26^{* * *}$ \\
& $(0.72)$ & $(0.84)$ & $(0.51)$ \\
\hline$R^{2}$ & 0.74 & 0.76 & 0.76 \\
\hline Cultural Associations pc 1997-2012 & $3.12^{* * *}$ & $3.88^{* * *}$ & $2.24^{* * *}$ \\
& $(0.10)$ & $(0.12)$ & $(0.08)$ \\
\hline$R^{2}$ & 0.91 & 0.90 & 0.88 \\
\hline Observations & 104 & 104 & 104 \\
\hline \hline
\end{tabular}

The dependent variable is the average value at the municipal level of the individuals' responses to the following questions. In column (1): "On a scale from 0 (none) to 10 (a lot), how do you value the level of civic behavior in your municipality?". In column (2): "Regarding the people in your neighborhood/municipality, how often do you interact with them on a scale from 0 (I do not interact with anybody) to 10 (I have relationships with many people)". In column (3): "Regarding the following problems: impoliteness of your neighbors, bad shape of urban amenities, noise, uncleanliness, presence of drug-users or drugdealers, disruptive youth, prostitutes, homeless people and beggars; how do you value your neighbors' behavior on a scale from 0 (they don't do anything about it) to 10 (they do a lot)?". The results shown are the coefficients of an OLS univariate regression with no controls and no constant term. Robust standard errors in parentheses. ${ }^{*} p<0.10$, ${ }^{* *} p<0.05,{ }^{* * *} p<0.01$. 
2013/1, Sánchez-Vidal, M.; González-Val, R.; Viladecans-Marsal, E.: "Sequential city growth in the US: does age matter?"

2013/2, Hortas Rico, M.: "Sprawl, blight and the role of urban containment policies. Evidence from US cities"

2013/3, Lampón, J.F.; Cabanelas-Lorenzo, P-; Lago-Peñas, S.: "Why firms relocate their production overseas? The answer lies inside: corporate, logistic and technological determinants"

2013/4, Montolio, D.; Planells, S.: "Does tourism boost criminal activity? Evidence from a top touristic country"

2013/5, Garcia-López, M.A.; Holl, A.; Viladecans-Marsal, E.: "Suburbanization and highways: when the Romans, the Bourbons and the first cars still shape Spanish cities"

2013/6, Bosch, N.; Espasa, M.; Montolio, D.: "Should large Spanish municipalities be financially compensated? Costs and benefits of being a capital/central municipality"

2013/7, Escardíbul, J.O.; Mora, T.: "Teacher gender and student performance in mathematics. Evidence from Catalonia"

2013/8, Arqué-Castells, P.; Viladecans-Marsal, E.: "Banking towards development: evidence from the Spanish banking expansion plan"

2013/9, Asensio, J.; Gómez-Lobo, A.; Matas, A.: "How effective are policies to reduce gasoline consumption? Evaluating a quasi-natural experiment in Spain"

2013/10, Jofre-Monseny, J.: "The effects of unemployment benefits on migration in lagging regions"

2013/11, Segarra, A.; García-Quevedo, J.; Teruel, M.: "Financial constraints and the failure of innovation projects"

2013/12, Jerrim, J.; Choi, A.: "The mathematics skills of school children: How does England compare to the high performing East Asian jurisdictions?"

2013/13, González-Val, R.; Tirado-Fabregat, D.A.; Viladecans-Marsal, E.: "Market potential and city growth: Spain 1860-1960"

2013/14, Lundqvist, H.: "Is it worth it? On the returns to holding political office"

2013/15, Ahlfeldt, G.M.; Maennig, W.: "Homevoters vs. leasevoters: a spatial analysis of airport effects"

2013/16, Lampón, J.F.; Lago-Peñas, S.: "Factors behind international relocation and changes in production geography in the European automobile components industry"

2013/17, Guío, J.M.; Choi, A.: "Evolution of the school failure risk during the 2000 decade in Spain: analysis of Pisa results with a two-level logistic mode"

2013/18, Dahlby, B.; Rodden, J.: "A political economy model of the vertical fiscal gap and vertical fiscal imbalances in a federation"

2013/19, Acacia, F.; Cubel, M.: "Strategic voting and happiness"

2013/20, Hellerstein, J.K.; Kutzbach, M.J.; Neumark, D.: "Do labor market networks have an important spatial dimension?"

2013/21, Pellegrino, G.; Savona, M.: "Is money all? Financing versus knowledge and demand constraints to innovation" 2013/22, Lin, J.: "Regional resilience"

2013/23, Costa-Campi, M.T.; Duch-Brown, N.; García-Quevedo, J.: "R\&D drivers and obstacles to innovation in the energy industry"

2013/24, Huisman, R.; Stradnic, V.; Westgaard, S.: "Renewable energy and electricity prices: indirect empirical evidence from hydro power"

2013/25, Dargaud, E.; Mantovani, A.; Reggiani, C.: "The fight against cartels: a transatlantic perspective"

2013/26, Lambertini, L.; Mantovani, A.: "Feedback equilibria in a dynamic renewable resource oligopoly: pre-emption, voracity and exhaustion"

2013/27, Feld, L.P.; Kalb, A.; Moessinger, M.D.; Osterloh, S.: "Sovereign bond market reactions to fiscal rules and nobailout clauses - the Swiss experience"

2013/28, Hilber, C.A.L.; Vermeulen, W.: "The impact of supply constraints on house prices in England"

2013/29, Revelli, F.: "Tax limits and local democracy"

2013/30, Wang, R.; Wang, W.: "Dress-up contest: a dark side of fiscal decentralization"

2013/31, Dargaud, E.; Mantovani, A.; Reggiani, C.: "The fight against cartels: a transatlantic perspective"

2013/32, Saarimaa, T.; Tukiainen, J.: "Local representation and strategic voting: evidence from electoral boundary reforms"

2013/33, Agasisti, T.; Murtinu, S.: "Are we wasting public money? No! The effects of grants on Italian university students' performances"

2013/34, Flacher, D.; Harari-Kermadec, H.; Moulin, L.: "Financing higher education: a contributory scheme"

2013/35, Carozzi, F.; Repetto, L.: "Sending the pork home: birth town bias in transfers to Italian municipalities"

2013/36, Coad, A.; Frankish, J.S.; Roberts, R.G.; Storey, D.J.: "New venture survival and growth: Does the fog lift?" 
2013/37, Giulietti, M.; Grossi, L.; Waterson, M.: "Revenues from storage in a competitive electricity market: Empirical evidence from Great Britain"

2014/1, Montolio, D.; Planells-Struse, S.: "When police patrols matter. The effect of police proximity on citizens' crime risk perception"

2014/2, Garcia-López, M.A.; Solé-Ollé, A.; Viladecans-Marsal, E.: "Do land use policies follow road construction?" 2014/3, Piolatto, A.; Rablen, M.D.: "Prospect theory and tax evasion: a reconsideration of the Yitzhaki puzzle"

2014/4, Cuberes, D.; González-Val, R.: "The effect of the Spanish Reconquest on Iberian Cities"

2014/5, Durán-Cabré, J.M.; Esteller-Moré, E.: "Tax professionals' view of the Spanish tax system: efficiency, equity and tax planning"

2014/6, Cubel, M.; Sanchez-Pages, S.: "Difference-form group contests"

2014/7, Del Rey, E.; Racionero, M.: "Choosing the type of income-contingent loan: risk-sharing versus risk-pooling"

2014/8, Torregrosa Hetland, S.: "A fiscal revolution? Progressivity in the Spanish tax system, 1960-1990"

2014/9, Piolatto, A.: "Itemised deductions: a device to reduce tax evasion"

2014/10, Costa, M.T.; García-Quevedo, J.; Segarra, A.: "Energy efficiency determinants: an empirical analysis of Spanish innovative firms"

2014/11, García-Quevedo, J.; Pellegrino, G.; Savona, M.: "Reviving demand-pull perspectives: the effect of demand uncertainty and stagnancy on R\&D strategy"

2014/12, Calero, J.; Escardíbul, J.O.: "Barriers to non-formal professional training in Spain in periods of economic growth and crisis. An analysis with special attention to the effect of the previous human capital of workers"

2014/13, Cubel, M.; Sanchez-Pages, S.: "Gender differences and stereotypes in the beauty"

2014/14, Piolatto, A.; Schuett, F.: "Media competition and electoral politics"

2014/15, Montolio, D.; Trillas, F.; Trujillo-Baute, E.: "Regulatory environment and firm performance in EU telecommunications services"

2014/16, Lopez-Rodriguez, J.; Martinez, D.: "Beyond the R\&D effects on innovation: the contribution of non-R\&D activities to TFP growth in the EU"

2014/17, González-Val, R.: "Cross-sectional growth in US cities from 1990 to 2000"

2014/18, Vona, F.; Nicolli, F.: "Energy market liberalization and renewable energy policies in OECD countries"

2014/19, Curto-Grau, M.: "Voters' responsiveness to public employment policies"

2014/20, Duro, J.A.; Teixidó-Figueras, J.; Padilla, E.: "The causal factors of international inequality in co2 emissions per capita: a regression-based inequality decomposition analysis"

2014/21, Fleten, S.E.; Huisman, R.; Kilic, M.; Pennings, E.; Westgaard, S.: "Electricity futures prices: time varying sensitivity to fundamentals"

2014/22, Afcha, S.; García-Quevedo, J,: "The impact of R\&D subsidies on R\&D employment composition"

2014/23, Mir-Artigues, P.; del Río, P.: "Combining tariffs, investment subsidies and soft loans in a renewable electricity deployment policy"

2014/24, Romero-Jordán, D.; del Río, P.; Peñasco, C.: "Household electricity demand in Spanish regions. Public policy implications"

2014/25, Salinas, P.: "The effect of decentralization on educational outcomes: real autonomy matters!"

2014/26, Solé-Ollé, A.; Sorribas-Navarro, P.: "Does corruption erode trust in government? Evidence from a recent surge of local scandals in Spain"

2014/27, Costas-Pérez, E.: "Political corruption and voter turnout: mobilization or disaffection?"

2014/28, Cubel, M.; Nuevo-Chiquero, A.; Sanchez-Pages, S.; Vidal-Fernandez, M.: "Do personality traits affect productivity? Evidence from the LAB"

2014/29, Teresa Costa, M.T.; Trujillo-Baute, E.: "Retail price effects of feed-in tariff regulation"

2014/30, Kilic, M.; Trujillo-Baute, E.: "The stabilizing effect of hydro reservoir levels on intraday power prices under wind forecast errors"

2014/31, Costa-Campi, M.T.; Duch-Brown, N.: "The diffusion of patented oil and gas technology with environmental uses: a forward patent citation analysis"

2014/32, Ramos, R.; Sanromá, E.; Simón, H.: "Public-private sector wage differentials by type of contract: evidence from Spain"

2014/33, Backus, P.; Esteller-Moré, A.: "Is income redistribution a form of insurance, a public good or both?"

2014/34, Huisman, R.; Trujillo-Baute, E.: "Costs of power supply flexibility: the indirect impact of a Spanish policy change" 
2014/35, Jerrim, J.; Choi, A.; Simancas Rodríguez, R.: "Two-sample two-stage least squares (TSTSLS) estimates of earnings mobility: how consistent are they?"

2014/36, Mantovani, A.; Tarola, O.; Vergari, C.: "Hedonic quality, social norms, and environmental campaigns" 2014/37, Ferraresi, M.; Galmarini, U.; Rizzo, L.: "Local infrastructures and externalities: Does the size matter?"

2014/38, Ferraresi, M.; Rizzo, L.; Zanardi, A.: "Policy outcomes of single and double-ballot elections"

2015/1, Foremny, D.; Freier, R.; Moessinger, M-D.; Yeter, M.: "Overlapping political budget cycles in the legislative and the executive"

2015/2, Colombo, L.; Galmarini, U.: "Optimality and distortionary lobbying: regulating tobacco consumption"

2015/3, Pellegrino, G.: "Barriers to innovation: Can firm age help lower them?"

2015/4, Hémet, C.: "Diversity and employment prospects: neighbors matter!"

2015/5, Cubel, M.; Sanchez-Pages, S.: "An axiomatization of difference-form contest success functions"

2015/6, Choi, A.; Jerrim, J.: "The use (and misuse) of Pisa in guiding policy reform: the case of Spain"

2015/7, Durán-Cabré, J.M.; Esteller-Moré, A.; Salvadori, L.: "Empirical evidence on tax cooperation between subcentral administrations"

2015/8, Batalla-Bejerano, J.; Trujillo-Baute, E.: "Analysing the sensitivity of electricity system operational costs to deviations in supply and demand"

2015/9, Salvadori, L.: "Does tax enforcement counteract the negative effects of terrorism? A case study of the Basque Country"

2015/10, Montolio, D.; Planells-Struse, S.: "How time shapes crime: the temporal impacts of football matches on crime" 2015/11, Piolatto, A.: "Online booking and information: competition and welfare consequences of review aggregators"

2015/12, Boffa, F.; Pingali, V.; Sala, F.: "Strategic investment in merchant transmission: the impact of capacity utilization rules"

2015/13, Slemrod, J.: "Tax administration and tax systems"

2015/14, Arqué-Castells, P.; Cartaxo, R.M.; García-Quevedo, J.; Mira Godinho, M.: "How inventor royalty shares affect patenting and income in Portugal and Spain"

2015/15, Montolio, D.; Planells-Struse, S.: "Measuring the negative externalities of a private leisure activity: hooligans and pickpockets around the stadium"

2015/16, Batalla-Bejerano, J.; Costa-Campi, M.T.; Trujillo-Baute, E.: "Unexpected consequences of liberalisation: metering, losses, load profiles and cost settlement in Spain's electricity system"

2015/17, Batalla-Bejerano, J.; Trujillo-Baute, E.: "Impacts of intermittent renewable generation on electricity system costs"

2015/18, Costa-Campi, M.T.; Paniagua, J.; Trujillo-Baute, E.: "Are energy market integrations a green light for FDI?" 2015/19, Jofre-Monseny, J.; Sánchez-Vidal, M.; Viladecans-Marsal, E.: "Big plant closures and agglomeration economies"

2015/20, Garcia-López, M.A.; Hémet, C.; Viladecans-Marsal, E.: "How does transportation shape intrametropolitan growth? An answer from the regional express rail"

2015/21, Esteller-Moré, A.; Galmarini, U.; Rizzo, L.: "Fiscal equalization under political pressures"

2015/22, Escardíbul, J.O.; Afcha, S.: "Determinants of doctorate holders' job satisfaction. An analysis by employment sector and type of satisfaction in Spain"

2015/23, Aidt, T.; Asatryan, Z.; Badalyan, L.; Heinemann, F.: "Vote buying or (political) business (cycles) as usual?"

2015/24, Albæk, K.: "A test of the 'lose it or use it' hypothesis in labour markets around the world"

2015/25, Angelucci, C.; Russo, A.: "Petty corruption and citizen feedback"

2015/26, Moriconi, S.; Picard, P.M.; Zanaj, S.: "Commodity taxation and regulatory competition"

2015/27, Brekke, K.R.; Garcia Pires, A.J.; Schindler, D.; Schjelderup, G.: "Capital taxation and imperfect competition: ACE vs. CBIT"

2015/28, Redonda, A.: "Market structure, the functional form of demand and the sensitivity of the vertical reaction function"

2015/29, Ramos, R.; Sanromá, E.; Simón, H.: "An analysis of wage differentials between full-and part-time workers in Spain"

2015/30, Garcia-López, M.A.; Pasidis, I.; Viladecans-Marsal, E.: "Express delivery to the suburbs the effects of transportation in Europe's heterogeneous cities"

2015/31, Torregrosa, S.: "Bypassing progressive taxation: fraud and base erosion in the Spanish income tax (19702001)" 
2015/32, Choi, H.; Choi, A.: "When one door closes: the impact of the hagwon curfew on the consumption of private tutoring in the republic of Korea"

2015/33, Escardíbul, J.O.; Helmy, N.: "Decentralisation and school autonomy impact on the quality of education: the case of two MENA countries"

2015/34, González-Val, R.; Marcén, M.: "Divorce and the business cycle: a cross-country analysis"

2015/35, Calero, J.; Choi, A.: "The distribution of skills among the European adult population and unemployment: a comparative approach"

2015/36, Mediavilla, M.; Zancajo, A.: "Is there real freedom of school choice? An analysis from Chile"

2015/37, Daniele, G.: "Strike one to educate one hundred: organized crime, political selection and politicians' ability"

2015/38, González-Val, R.; Marcén, M.: "Regional unemployment, marriage, and divorce"

2015/39, Foremny, D.; Jofre-Monseny, J.; Solé-Ollé, A.: "'Hold that ghost': using notches to identify manipulation of population-based grants"

2015/40, Mancebón, M.J.; Ximénez-de-Embún, D.P.; Mediavilla, M.; Gómez-Sancho, J.M.: "Does educational management model matter? New evidence for Spain by a quasiexperimental approach"

2015/41, Daniele, G.; Geys, B.: "Exposing politicians' ties to criminal organizations: the effects of local government dissolutions on electoral outcomes in Southern Italian municipalities"

2015/42, Ooghe, E.: "Wage policies, employment, and redistributive efficiency"

\section{6}

2016/1, Galletta, S.: "Law enforcement, municipal budgets and spillover effects: evidence from a quasi-experiment in Italy"

2016/2, Flatley, L.; Giulietti, M.; Grossi, L.; Trujillo-Baute, E.; Waterson, M.: "Analysing the potential economic value of energy storage"

2016/3, Calero, J.; Murillo Huertas, I.P.; Raymond Bara, J.L.: "Education, age and skills: an analysis using the PIAAC survey"

2016/4, Costa-Campi, M.T.; Daví-Arderius, D.; Trujillo-Baute, E.: "The economic impact of electricity losses"

2016/5, Falck, O.; Heimisch, A.; Wiederhold, S.: "Returns to ICT skills"

2016/6, Halmenschlager, C.; Mantovani, A.: "On the private and social desirability of mixed bundling in complementary markets with cost savings"

2016/7, Choi, A.; Gil, M.; Mediavilla, M.; Valbuena, J.: "Double toil and trouble: grade retention and academic performance"

2016/8, González-Val, R.: "Historical urban growth in Europe (1300-1800)"

2016/9, Guio, J.; Choi, A.; Escardíbul, J.O.: "Labor markets, academic performance and the risk of school dropout: evidence for Spain"

2016/10, Bianchini, S.; Pellegrino, G.; Tamagni, F.: "Innovation strategies and firm growth"

2016/11, Jofre-Monseny, J.; Silva, J.I.; Vázquez-Grenno, J.: "Local labor market effects of public employment"

2016/12, Sanchez-Vidal, M.: "Small shops for sale! The effects of big-box openings on grocery stores"

2016/13, Costa-Campi, M.T.; García-Quevedo, J.; Martínez-Ros, E.: "What are the determinants of investment in environmental R\&D?"

2016/14, García-López, M.A; Hémet, C.; Viladecans-Marsal, E.: "Next train to the polycentric city: The effect of railroads on subcenter formation"

2016/15, Matas, A.; Raymond, J.L.; Dominguez, A.: "Changes in fuel economy: An analysis of the Spanish car market" 2016/16, Leme, A.; Escardíbul, J.O.: "The effect of a specialized versus a general upper secondary school curriculum on students' performance and inequality. A difference-in-differences cross country comparison"

2016/17, Scandurra, R.I.; Calero, J.: "Modelling adult skills in OECD countries"

2016/18, Fernández-Gutiérrez, M.; Calero, J.: "Leisure and education: insights from a time-use analysis"

2016/19, Del Rio, P.; Mir-Artigues, P.; Trujillo-Baute, E.: "Analysing the impact of renewable energy regulation on retail electricity prices"

2016/20, Taltavull de la Paz, P.; Juárez, F.; Monllor, P.: "Fuel Poverty: Evidence from housing perspective"

2016/21, Ferraresi, M.; Galmarini, U.; Rizzo, L.; Zanardi, A.: "Switch towards tax centralization in Italy: A wake up for the local political budget cycle"

2016/22, Ferraresi, M.; Migali, G.; Nordi, F.; Rizzo, L.: "Spatial interaction in local expenditures among Italian municipalities: evidence from Italy 2001-2011"

2016/23, Daví-Arderius, D.; Sanin, M.E.; Trujillo-Baute, E.: "CO2 content of electricity losses" 
2016/24, Arqué-Castells, P.; Viladecans-Marsal, E.: "Banking the unbanked: Evidence from the Spanish banking expansion plan"

2016/25 Choi, Á.; Gil, M.; Mediavilla, M.; Valbuena, J.: “The evolution of educational inequalities in Spain: Dynamic evidence from repeated cross-sections"

2016/26, Brutti, Z.: "Cities drifting apart: Heterogeneous outcomes of decentralizing public education" 2016/27, Backus, P.; Cubel, M.; Guid, M.; Sánchez-Pages, S.; Lopez Manas, E.: "Gender, competition and performance: evidence from real tournaments"

2016/28, Costa-Campi, M.T.; Duch-Brown, N.; García-Quevedo, J.: "Innovation strategies of energy firms" 2016/29, Daniele, G.; Dipoppa, G.: "Mafia, elections and violence against politicians"

2016/30, Di Cosmo, V.; Malaguzzi Valeri, L.: "Wind, storage, interconnection and the cost of electricity"

2017/1, González Pampillón, N.; Jofre-Monseny, J.; Viladecans-Marsal, E.: "Can urban renewal policies reverse neighborhood ethnic dynamics?"

2017/2, Gómez San Román, T.: "Integration of DERs on power systems: challenges and opportunities"

2017/3, Bianchini, S.; Pellegrino, G.: "Innovation persistence and employment dynamics"

2017/4, Curto-Grau, M.; Solé-Ollé, A.; Sorribas-Navarro, P.: "Does electoral competition curb party favoritism?"

2017/5, Solé-Ollé, A.; Viladecans-Marsal, E.: "Housing booms and busts and local fiscal policy"

2017/6, Esteller, A.; Piolatto, A.; Rablen, M.D.: "Taxing high-income earners: Tax avoidance and mobility"

2017/7, Combes, P.P.; Duranton, G.; Gobillon, L.: "The production function for housing: Evidence from France"

2017/8, Nepal, R.; Cram, L.; Jamasb, T.; Sen, A.: "Small systems, big targets: power sector reforms and renewable energy development in small electricity systems"

2017/9, Carozzi, F.; Repetto, L.: "Distributive politics inside the city? The political economy of Spain's plan E"

2017/10, Neisser, C.: "The elasticity of taxable income: A meta-regression analysis"

2017/11, Baker, E.; Bosetti, V.; Salo, A.: "Finding common ground when experts disagree: robust portfolio decision analysis"

2017/12, Murillo, I.P; Raymond, J.L; Calero, J.: "Efficiency in the transformation of schooling into competences: A cross-country analysis using PIAAC data"

2017/13, Ferrer-Esteban, G.; Mediavilla, M.: "The more educated, the more engaged? An analysis of social capital and education"

2017/14, Sanchis-Guarner, R.: "Decomposing the impact of immigration on house prices"

2017/15, Schwab, T.; Todtenhaupt, M.: "Spillover from the haven: Cross-border externalities of patent box regimes within multinational firms"

2017/16, Chacón, M.; Jensen, J.: "The institutional determinants of Southern secession"

2017/17, Gancia, G.; Ponzetto, G.A.M.; Ventura, J.: "Globalization and political structure"

2017/18, González-Val, R.: "City size distribution and space"

2017/19, García-Quevedo, J.; Mas-Verdú, F.; Pellegrino, G.: "What firms don’t know can hurt them: Overcoming a lack of information on technology"

2017/20, Costa-Campi, M.T.; García-Quevedo, J.: "Why do manufacturing industries invest in energy R\&D?"

2017/21, Costa-Campi, M.T.; García-Quevedo, J.; Trujillo-Baute, E.: "Electricity regulation and economic growth"

2018

2018/1, Boadway, R.; Pestieau, P.: "The tenuous case for an annual wealth tax"

2018/2, Garcia-López, M.À.: "All roads lead to Rome ... and to sprawl? Evidence from European cities"

2018/3, Daniele, G.; Galletta, S.; Geys, B.: “Abandon ship? Party brands and politicians' responses to a political scandal"

2018/4, Cavalcanti, F.; Daniele, G.; Galletta, S.: "Popularity shocks and political selection"

2018/5, Naval, J.; Silva, J. I.; Vázquez-Grenno, J.: "Employment effects of on-the-job human capital acquisition"

2018/6, Agrawal, D. R.; Foremny, D.: "Relocation of the rich: migration in response to top tax rate changes from spanish reforms"

2018/7, García-Quevedo, J.; Kesidou, E.; Martínez-Ros, E.: “Inter-industry differences in organisational ecoinnovation: a panel data study"

2018/8, Aastveit, K. A.; Anundsen, A. K.: "Asymmetric effects of monetary policy in regional housing markets" 
2018/9, Curci, F.; Masera, F.: "Flight from urban blight: lead poisoning, crime and suburbanization" 2018/10, Grossi, L.; Nan, F.: "The influence of renewables on electricity price forecasting: a robust approach" 2018/11, Fleckinger, P.; Glachant, M.; Tamokoué Kamga, P.-H.: "Energy performance certificates and investments in building energy efficiency: a theoretical analysis"

2018/12, van den Bergh, J. C.J.M.; Angelsen, A.; Baranzini, A.; Botzen, W.J. W.; Carattini, S.; Drews, S.; Dunlop, T.; Galbraith, E.; Gsottbauer, E.; Howarth, R. B.; Padilla, E.; Roca, J.; Schmidt, R.: "Parallel tracks towards a global treaty on carbon pricing"

2018/13, Ayllón, S.; Nollenberger, N.: "The unequal opportunity for skills acquisition during the Great Recession in Europe"

2018/14, Firmino, J.: "Class composition effects and school welfare: evidence from Portugal using panel data"

2018/15, Durán-Cabré, J. M.; Esteller-Moré, A.; Mas-Montserrat, M.; Salvadori, L.: "La brecha fiscal: estudio y aplicación a los impuestos sobre la riqueza" 


\section{IEB}

Institut

d'Economia

de Barcelona

\section{UNIVERS ITAT ${ }_{D E}$} BARCELONA 